\title{
Development of a novel cellular model of Alzheimer's disease utilizing neurosphere cultures derived from B6C3-Tg(APPswe,PSEN1dE9)85Dbo/J embryonic mouse brain
}

\author{
Pankaj S Ghate', Himakshi Sidhar ${ }^{1}$, George A Carlson² and Ranjit K Giri ${ }^{1,3^{*}}$
}

\begin{abstract}
Increased production, oligomerization and aggregation of amyloid- $\beta$ (A $\beta$ ) peptides are hallmark pathologies of Alzheimer's disease (AD). Expressing familial AD mutations (amyloid precursor protein and/or presenilins mutations), the A $\beta$-pathologies of AD has been recapitulated in animal models of AD. Very few primary cell culture-based models of AD are available and they exhibit very weak A $\beta$-pathologies compared to what is seen in AD patients and animal models of AD. CNS stem/progenitor cells are present in both embryonic and adult brains. They can be isolated, grown as neurospheres and differentiated into neurons, astrocytes and oligodendrocytes. It is not yet known whether CNS stem/progenitor cells can support the production of $A \beta$ peptides in culture. In this report, we have established $A \beta$-pathologies such as production, secretion, oligomerization and aggregation of $A \beta$ peptides utilizing neurosphere cultures to create a new cellular model of AD. These cultures were developed from E15 embryonic brains of transgenic mice carrying the Swedish mutations in humanized mouse APP CDNA and the exon-9 deleted human presenilin 1 cDNA both regulated by mouse prion protein gene (Prnp) promoter. Results demonstrated the expression of transgene transcripts, APPswe protein and its processed products only in transgene positive neurosphere cultures. These cultures generate and secrete both $A \beta 40$ and $A \beta 42$ peptides into culture medium at levels comparable to the $A \beta$ load in the brain of AD patients and animal models of $A D$, and produce pathogenic oligomers of $A \beta$ peptides. The $A \beta 42 / A \beta 40$ ratio in the medium of transgene positive neurosphere cultures is higher than any known cellular models of AD. Conformation dependent immunocytochemistry demonstrated the possible presence of intracellular and extracellular aggregation of A peptides in neurosphere cultures, which are also seen in AD brain and animal models of AD. Collectively, our neurosphere cultures provide robust A $\beta$-pathologies of AD better than existing cellular model of Alzheimer's disease.
\end{abstract}

Keywords: Neurosphere; Transgenic; APPswe; PSEN1dE9; Cellular model; Alzheimer's disease; Amyloid- $\beta$

\section{Introduction}

Alzheimer's disease (AD) is a chronic, irreversible and progressive neurodegenerative disease. $\mathrm{AD}$ is characterized by extracellular deposition of amyloid- $\beta$ (A $\beta$ ) peptides as senile plaques (Glenner and Wong 1984), intraneuronal neurofibrillary tangles (NFT) (Kosik et al. 1986; Wood et al. 1986), astrogliosis (Rodriguez et al. 2009), microglial activation (Giri et al. 2003) and loss of synapses and neurons in

\footnotetext{
* Correspondence: ranjitkgiri@hotmail.com

'National Brain Research Centre, Manesar, Haryana, India

${ }^{3}$ Molecular and Cellular Neuroscience Division, National Brain Research

Centre, Manesar, Haryana 122051, India

Full list of author information is available at the end of the article
}

the brain (Selkoe 2002; Whitehouse et al. 1982). Genetic linkage analysis of familial Alzheimer's disease (FAD) identified amyloid precursor protein (APP) (Chartier-Harlin et al. 1991; Goate et al. 1991; St George-Hyslop et al. 1987) and presenilins i.e. PSEN1 (Citron et al. 1997; Sherrington et al. 1995) and PSEN2 (Levy-Lahad et al. 1995) as the causative genes in FAD. Mutations in these genes are linked to increased $A \beta$ formation, specifically the more fibrillogenic A $\beta 42$ peptides (Borchelt et al. 1996b; Scheuner et al. 1996; Tomita et al. 1997), which led to the formulation of the amyloid- $\beta$ cascade hypothesis. The amyloid- $\beta$ cascade hypothesis states that $A \beta$ production is the earliest event 
in the cascade that eventually leads to AD associated neurodegeneration (Hardy and Allsop 1991; Sommer 2002). Utilizing this hypothesis, transgenic animals were created using human genes linked to FAD such as APP and PSEN1. These transgenic animals show increased production and deposition of $\mathrm{A} \beta$ peptides (senile plaques) and memory impairments. However, the majority of such AD animal models take upto a year to develop signs of disease in the brain (Eimer and Vassar 2013; Youmans et al. 2012). Therefore, quicker, cheaper and reproducible alternative models were explored utilizing cell culture based systems.

Various cancerous cell lines (Wang et al. 2000) and primary cortical neurons (LeBlanc 1995; Lorenzo and Yankner 1994; Takashima et al. 1993; Yankner et al. 1990) have been extensively utilized to study the toxic effect of $A \beta$ peptides. Cancerous cell lines with neuronal origin (Borchelt et al. 1996b; Cai et al. 1993) and nonneuronal origin (Citron et al. 1997; Haass et al. 1992) that express FAD genes produce $\mathrm{A} \beta$ peptides and are useful for the study of $A \beta$ genesis, stability and intracellular trafficking (Vassar et al. 1999; Wertkin et al. 1993). However, these models are limited by their genetic instability over multiple passages, their rapid growth rate and their inability to model mature brain cell types. Primary cell cultures expressing FAD genes may model $\mathrm{AD}$ better in vitro, and thus warrant investigation. Primary hippocampal cell cultures from transgenic animal models for AD express $\mathrm{A} \beta$ peptides endogenously (Trinchese et al. 2004; Yun et al. 2007). However, these cultures are difficult to maintain for more than 3 weeks (Brewer and Torricelli 2007) and cannot be passaged. Therefore, long-term experimentation and need for repetition demands frequent tissue harvests when using this system. Similarly, slice cultures cannot be maintained for more than few weeks (De Simoni and Yu 2006). It has been well documented that, CNS stem/progenitor cells are present in both embryonic and adult brain. These cells can be isolated and grown as neurospheres in substrate free vessels over several passages like transformed cell lines and maintain the properties of stem/progenitor cells (Brustle et al. 1997; Ray and Gage 2006; Reynolds and Weiss 1992; Uchida et al. 2000). Most importantly, neurosphere cultures can be differentiated into major cell types of an adult brain such as neurons, astrocytes and oligodendrocytes (Gritti et al. 1996; Ray and Gage 2006). Although neural stem cells have been utilized to study the effect of $A \beta$ peptides, to our knowledge, there is no report indicating the use of CNS stem/progenitor cells to model beta amyloid pathology of AD in vitro.

In the present report, we have combined the transgenic and CNS stem/progenitor cell culture technologies to develop a novel platform to model the pathological processing of mutant human APPswe protein for $A \beta$ genesis, oligomerization and aggregation, the initial events of AD pathogenesis. Neurosphere cultures were established from AD transgenic (APPswe,PSEN1dE9) mice embryos. Neurosphere cultures positive for transgenes $(\mathrm{Tg}+\mathrm{ve})$ express both transgenes at the mRNA level and express humanized APP and its proteolytic products including $\mathrm{A} \beta$ peptides. Analysis of $\mathrm{Tg}+\mathrm{ve}$ neurosphere lysates demonstrated the presence of both monomeric and various oligomeric $\mathrm{A} \beta$ peptides similar to an 18-month old $\mathrm{Tg}+\mathrm{ve}$ mouse brain homogenate. $\mathrm{Tg}+\mathrm{ve}$ neurosphere cultures secrete a large amount of human $\mathrm{A} \beta$ peptides that consist of $A \beta 40$ and $A \beta 42$ with a very high $A \beta 42$ / $\mathrm{A} \beta 40$ ratio comparable to that of human $\mathrm{AD}$ brain homogenates and more than any cellular model of AD. Tg+ve culture supernatants also contain monomeric and various pathogenic $A \beta$ peptide oligomers (ranging from 2-mer to 12-mer; the A $\beta$ star oligomer). In addition, conformation-dependent immunocytochemistry demonstrated the presence of intracellular and extracellular $A \beta$ peptides within neurospheres. Thus, our results provide compelling evidence for $\mathrm{A} \beta$ peptide genesis, secretion, oligomerization and aggregation in $\mathrm{Tg}+\mathrm{ve}$ neurosphere cultures better than any existing cellular model of AD.

\section{Materials and methods}

\section{Ethics statement}

All experiments on animals were conducted in accordance with guidelines approved by the committee for the purpose of control and supervision of experiments on animals (Regd. No. 464/a/CPCSEA). All animal procedures were reviewed and approved by National Brain Research Centre (NBRC) animal ethics committee (NBRC/ IAEC/2008/44).

\section{Mice}

B6C3-Tg(APPswe,PSEN1dE9)85Dbo/J mice were obtained from the Jackson Laboratory (Bar Harbor, Maine, USA) and maintained as a mouse line in NBRC. Tg+ve mice express APPswe (K670N and M671L) mutations in humanized mouse APP cDNA and exon 9-deleted human presenilin 1 (PSEN1dE9) cDNA under the control of the mouse prion protein (Prnp) gene promoter. Both these transgenes are integrated at a same locus resulting 50\% of litters are hemizygous for both APPswe and PSEN1dE9 transgenes and rest $50 \%$ as wild type controls from a cross between hemizygous transgenics to wild type (Borchelt et al. 1996a; Jankowsky et al. 2004).

\section{Antibodies}

Beta amyloid 1-16 monoclonal antibody (6E10), which is specific for human APP and some of its proteolytic products including $A \beta$ peptides and anti-A $\beta 42$ antibody (BA3-9) specific for human A $\beta 42$ were purchased from Covance. Anti-nestin antibody was purchased from 
Chemicon. Anti-GAPDH, anti- $\beta$-tubulin III and anti-glial fibrillary acidic protein (GFAP) antibodies were purchased from Santacruz, Sigma-Aldrich and DAKO respectively. Secondary antibodies conjugated with HRP and Alexafluorophores were purchased from Pierce and Invitrogen respectively.

\section{Isolation of DNA and genotyping}

Total genomic DNA was isolated from the tail of mouse during weaning using QIAamp DNA Mini kit (Qiagen). Genomic DNA ( $1 \mu \mathrm{l})$ was used to amplify huAPPswe and huPSEN1dE9 transgenes by polymerase chain reaction (PCR). Primers for APP and PSEN1 transgenes were purchased from Sigma. Primers sequences were obtained from the Jackson Laboratory. PCR products were resolved on $2 \%$ agarose gel and digital images of ethidium bromide stained gels were captured using ChemiDoc $\mathrm{XRS}^{+}$gel doc system (BIO-RAD, USA).

\section{Neurosphere isolation}

Embryos from a wild type female mouse bred with a hemizygous $\operatorname{Tg}($ APPswe,PSEN1dE9) male mouse were harvested on embryonic date 15 (E15) and neurosphere (NS) cultures were isolated using earlier protocol (Giri et al. 2006). Briefly, whole brain was isolated from each embryo and triturated in $1 \mathrm{ml}$ of neurobasal media supplemented with glutamax and antibiotics (all from Invitrogen, USA) using filtered $200 \mu \mathrm{l}$ tips to obtain homogeneous cell suspension. Each cell suspension was diluted further to $10 \mathrm{ml}$ using same media and filtered through $45 \mu \mathrm{m}$ mesh (Falcon, USA). The filtrates were centrifuged at $1000 \mathrm{rpm}$ $(\sim 100 \times \mathrm{g})$ for $5 \mathrm{~min}$ at room temperature (RT). Cell pellets were gently triturated through filtered $200 \mu \mathrm{l}$ tips and cultured in T75 non-adherent culture flask (Nunc, USA) in $15 \mathrm{ml}$ of complete neurobasal media (neurobasal media supplemented with N2 supplement (1X), 2 mM Glutamax, Penicillin-streptomycin mix (1X), $20 \mathrm{ng} / \mathrm{ml}$ of recombinant huEGF, $10 \mathrm{ng} / \mathrm{ml}$ of recombinant huFGF-b (all from Invitrogen, USA) and $10 \mathrm{ng} / \mathrm{ml}$ of recombinant mouse LIF (Chemicon, USA). After 2-3 days in culture, distinct cell clumps were seen, collected and recultured in complete neurobasal media. After every 3-4 days, 50\% of media was replaced with fresh complete neurobasal media. Usually, distinct spheres of cells are visible by 4-7 days of culture. These cultures took approximately one month of time to grow sufficiently to warrant further passage. Neurospheres were split at 1:3 ratios by triturating NS pellets. It is important to stress here that our culture system favors slower growth than others but was developed to allow infection by RML scrapie prions in NS cultures (Giri et al. 2006). Neurosphere culture conditions that favor faster growth are not infected with prions (Herva et al. 2010). Although our cultures grow slowly, they are highly enriched with nestin positive cells (CNS stem/progenitor cells) and generate neurons and astrocytes after differentiation (data not shown). Therefore, in this report, we have employed slow growing NS culture protocol to model $A \beta$ genesis, oligomerization and aggregation in vitro. Genomic DNA from each NS line and mother's tail were isolated and genotyped for transgenes as mentioned above. Nine NS lines have been established out of which, NS1-4 are used extensively in this report. Furthermore, two additional Tg-ve NS lines (NS6 and 7) were also used.

\section{Isolation of RNA}

Total RNA was isolated from each NS culture using Trizol reagents (Invitrogen). Twenty microgram $(\mu \mathrm{g})$ of total RNA was treated with amplification grade and RNase free DNase I (Invitrogen) as per manufacturer's protocol. Concentration of RNA was measured using NanoVue Plus spectrophotometer (GE).

\section{RT-PCR}

Twenty-five nanogram of DNase I treated total RNA from each NS line was reverse transcribed for cDNA preparation. HuAPPswe, huPSEN1dE9 and GAPDH transcripts were amplified by one-step reverse transcriptase PCR (RT-PCR) employing manufacturer's protocol (Qiagen). The following primers were used for RT-PCR: APPswe, forward: $5^{\prime}$-TTCCCGTGAATGGAGAGAGTT C-3'; reverse: 5'-ATGAACTTCATATCCTGAGTCATG TCG-3', PSEN1dE9, forward: 5'-GGTCCACTTCGTAT GCTGGT-3'; reverse: 5'-TTCCCATTCCTCACTGAAC C-3'. Primers for GAPDH were similar to that reported earlier (Usenko et al. 2009). PCR products were resolved using $2 \%$ agarose gel electrophoresis and digital images of ethidium bromide stained DNA fragments were captured in ChemiDoc $\mathrm{XRS}^{+}$gel doc system.

\section{Detection of huAPPswe protein in neurosphere lysates}

Neurospheres were harvested at the end of each passage by centrifuging the culture at $1000 \mathrm{rpm}$ for 5 minutes at room temperature. Neurosphere pellets were lysed in RIPA buffer (150 mM NaCl; $10 \mathrm{mM}$ Tris, pH 7.4; 0.5\% Triton-X 100; $0.5 \%$ sodium deoxycholate; $0.1 \%$ SDS and $1 \mathrm{X}$ protease inhibitor cocktail). Protein concentration was determined by micro BCA protein assay kit (Pierce). Sixty $\mu$ g of total protein was size fractionated in $15 \%$ Tris-Glycine polyacrylamide gel along with brain homogenates from 18-months old $\mathrm{Tg}+\mathrm{ve}$ and $\mathrm{Tg}$-ve control mice. A $\beta 42$ was used as an additional positive control. Proteins were then transferred onto $0.2 \mu \mathrm{m}$ PVDF membranes. Blots were incubated for $10 \mathrm{~min}$ in boiling phosphate buffered saline (PBS) bath for epitope retrieval (Ida et al. 1996; Swerdlow et al. 1986) followed by immunoblotting with 1000-fold diluted 6E10 antibody. The secondary antibody, anti-mouse IgG conjugated with HRP was used to visualize the bands and by using 
supersignal west pico chemiluminescent kit (Pierce) on $\mathrm{X}$-ray film (Amersham). Time-lapse digital images were also captured using ChemiDoc $\mathrm{XRS}^{+}$gel doc system. Digital images without saturation were used for densitometric and molecular weight analysis with ImageLab (version 3.0) software.

\section{Detection of $A \beta$ peptides in culture media}

Culture media from $\mathrm{Tg}$-ve and $\mathrm{Tg}+\mathrm{ve}$ neurosphere lines were collected at the end of each passage and after 4 days of media change. Culture media were centrifuged at $100 \times \mathrm{g}$ for 5 minutes at RT to sediment neurospheres, small cell clumps and cell debris. Twenty-three milliliters (ml) of culture medium were spin filtered in two batches in an Amicon ultra 15 (or $8 \mathrm{ml}$ of medium in Amicon ultra 4) centrifugal filter (Millipore), which retain all proteins above $3 \mathrm{kDa}$ using manufacturer's protocol. Retentates were collected, aliquoted and stored at $-80^{\circ} \mathrm{C}$. Protein concentration, western blotting and immunoblotting with $6 \mathrm{E} 10$ antibody were perfomed as described earlier. To differentiate $A \beta 40$ and $A \beta 42$ peptides in the $A \beta$ pool of culture supernatant, $60 \mu \mathrm{g}$ of concentrated culture supernatants along with $5 \mathrm{ng}$ of each $\mathrm{A} \beta 40$ and $A \beta 42$ peptides (as positive controls) were size fractionated in $10 \%$ Bicine-Tris-Urea-polyacrylamide gel as described earlier (Wiltfang et al. 1997). Western blotting and detection of $\mathrm{A} \beta$ peptides was performed using 6E10 antibody. Imaging and densitometric analysis were performed as described above.

\section{Immunocytochemistry}

Neurospheres were triturated to obtain single cells or small cell clumps preparation. Approximately, 100000 cells were seeded onto poly-D-lysine (PDL) coated 24-well cover glass plates (Greiner) or onto PDL coated precleaned $12 \mathrm{~mm}$ diameter glass coverslips. Cells were grown in complete medium for 3 days with a medium change after 1 day of seeding. After removing the medium and three PBS washes, cells were fixed in $4 \%$ formaldehyde (PFA) for $30 \mathrm{mi}$ nutes at RT. Cells were washed thrice with PBS for 5 min each followed by permeabilization with $0.3 \%$ Triton-X 100 in PBS for 5 minutes at RT. Cells were blocked with $10 \%$ normal goat serum in washing buffer $\left(0.1 \%\right.$ BSA, $0.05 \% \mathrm{NaN}_{3}$ in $1 \mathrm{X}$ PBS) for 1 hour at RT followed by overnight incubation with primary antibodies at $4^{\circ} \mathrm{C}$. Cells were then washed five times (5 minutes each) followed by incubation with appropriate secondary antibodies conjugated with either Alexa 488 or Alexa 594 fluorophores for 1 hour at RT. After series of washes, cells were mounted in prolong gold anti-fade reagent containing DAPI (Molecular Probes).

\section{Conformation dependent immunocytochemistry (CDIC)}

Under physiological conditions, $A \beta$ peptides undergo conformational changes to form $\beta$-sheet, which are not efficiently reactive with 6E10 antibody (Rosen et al. 2010). Upon denaturation by formic acid (FA), the epitope of $A \beta$ peptides of various oligomers and conformers unfolds and binds efficiently with $6 \mathrm{E} 10$ antibody. Such mechanisms were exploited to detect the possible presence of $A \beta$ peptides within and outside the cells in neurospheres. In neurosphere monolayer cultures, cells were fixed and permeabilized. One group of NS cultures from each line was treated with 70\% FA for 1 hour at RT and the other group left untreated. Immunostaining was performed using 6E10 antibody as described earlier. To detect intracellular and extracellular $A \beta$ peptides within neurospheres, fixation of neurospheres was performed in 4\% PFA overnight followed by serial passaging through 10\%, 20\% and 30\% sucrose in PBS. Neurospheres were embedded in cryomedium and frozen in an ethanoldry ice bath. Ten $\mu \mathrm{m}$ thick frozen NS sections were obtained using a cryotome (Leica). Immunodetection of $\mathrm{A} \beta$ peptides with or without $70 \%$ FA treatment was similar to that described above. In addition to $6 \mathrm{E} 10$, an antibody specific for $A \beta 42$ peptide was used to detect $A \beta 42$ peptides in NS sections exposed or not exposed to formic acid.

\section{Image acquisition and analysis}

Images of all the samples within an experiment were acquired during the same session by using identical image acquisition settings for each fluorophore. For epifluorescence imaging, digital images were acquired at best focal plane using 40X planfluor objective lens and Axiocam HR RGB camera in a ZEISS Axiovert $200 \mathrm{M}$ microscope supported by AxiovisionRel (version 4.6.3.0) software. Densitometric analysis of images was performed using ImageJ 1.42q software (NIH). Regions with same area were drawn around the cell body of individual non-overlapping cells and mean fluorescence intensity (gray) value for individual cell was measured. After background subtraction, mean gray values were compared between transgene negative and positive groups. For confocal imaging of neurosphere sections, $63 \mathrm{X}$ oil, 12 bits multi-stack (at $0.5 \mu \mathrm{m}$ interval) images were acquired by LSM 510 confocal microscope (Zeiss). Maximum intensity projection of central three sections was made and analyzed. For analysis, a fix sized region tool was made and mean gray values from 25 non-overlapping regions within the image containing cell mass were obtained. Same region tool was used on images captured from one experiment in one sitting. Areas without cell mass were excluded. This approach was adopted as some neurospheres had more hollow space than others. 


\section{Statistical analysis}

Statistical analysis was performed by one-way ANOVA when data passed normality and equal variance test using Sigmastat 3.5 software. When data failed the above test, the groups were compared by non-parametric Kruskal-Wallis one-way ANOVA on ranks. In addition, non-parametric Dunn's method was employed to analyze pair-wise multiple comparisons. T-test was also calculated using Excel (Microsoft). p-value $\leq 0.05$ is considered statistically significant.

\section{Results}

Development of CNS stem/progenitor cells (neurosphere) cultures from B6C3-Tg(APPswe,PSEN1dE9)85Dbo/J mice

Embryonic day 15 (E15) brain cells isolated from B6C3$\mathrm{Tg}$ (APPswe,PSEN1dE9)85Dbo/J mice grew as balls of cells termed as neurospheres (NS) within 4-5 days in culture (Figure 1A). PCR assay for huAPPswe and huPSEN1dE9 transgenes demonstrated the amplification of a 350-bp and a 608-bp DNA fragments respectively from NS1, NS3 and a Tg+ve mouse genomic DNA but not from NS2 and NS4 lines (Figure 1B) showing that, NS1 and NS3 lines are Tg+ve, whereas NS2 and NS4 are Tg-ve. Similar results were obtained at passages 0, 5 and 12 (data not shown). Neurosphere lines 5-9 were also genotyped. NS5, 8 and 9 were Tg+ve and NS6 and 7 were Tg-ve (data not shown). Immunocytochemical analysis of nestin on adherent cells from NS1-4 cultures indicated the expression of nestin in a majority of cells (Figure 1C).
Cells without any antibody treatment (none) or treated with secondary antibody (Sec. ab.), show minimal immunosignal, indicating that both $\mathrm{Tg}$-ve and $\mathrm{Tg}+\mathrm{ve}$ NS lines express nestin, the most commonly used marker for CNS stem cells (Lendahl et al. 1990). Cell scoring analysis indicates that more than $75 \%$ of cells are positive for nestin in all the NS lines studied and no significant difference was observed between Tg+ve and Tg-ve lines (ANOVA, $\mathrm{n}=4$, $\mathrm{F}=0.174, \mathrm{p}=0.912$ ) (Figure 1D). When monolayer cultures from NS lines were co-immunostained with nestin and GFAP (a marker for glial cells), some cells are found to be co-stained for nestin and GFAP (Figure 2A). Cell type analysis in three independent experiments indicates approximately $21.6 \pm 1.46,13.6 \pm 10.1,17.3 \pm 3.66$ and $8.7 \pm 1.1$ percent of total cells were positive for both nestin and GFAP expression in NS2, NS4, NS1 and NS3 cultures respectively (Figure 2B). In addition, when cells were co-immunostained with nestin and $\beta$-tubulin III (a marker for young and mature neuron), approximately $19.3 \pm 8.5,16.4 \pm 5.6,8.7 \pm 6.3$ and $56.4 \pm 4.6$ percent of total cells are positive for both nestin and $\beta$-tubulin III (Figure 3A \& B). Collectively, our NS cultures are enriched with CNS stem/progenitor cells.

\section{APPswe and PSEN1dE9 transgene arrays are} transcriptionally active and large numbers of cells express nestin and APP proteins in $\mathrm{Tg}+\mathrm{ve}$ neurosphere lines Reverse transcription and PCR analysis on DNase I treated RNA isolated from NS1-4 cultures demonstrated
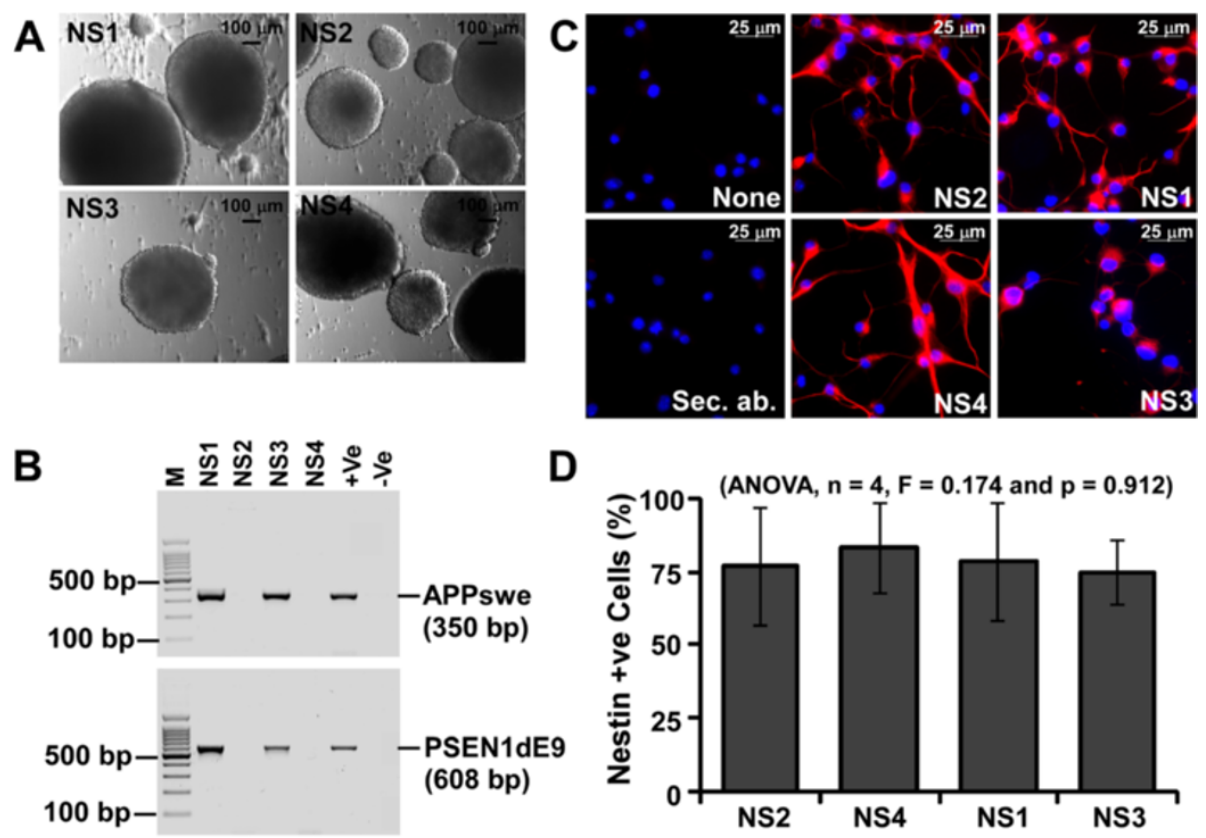

Figure 1 Development of neurosphere (NS) cultures from B6C3-Tg(APPswe,PSEN1dE9)85Dbo/J E15 embryos. (A) Cells from four mouse embryos (E15) were isolated and grown in non-treated tissue culture flasks to form neurospheres (NS1-NS4). (B) Genotyping of NS1-NS4 for huAPPswe (350-bp) and huPSEN1dE9 (608-bp) transgenes by PCR. (C) Expression of nestin in NS1-4 lines by immunofluorocytochemistry. (D) Cell type analysis of nestin expression in NS1-NS4 lines is represented as histograms of mean \pm standard deviation $($ ANOVA, $n=4, F=0.174, p=0.912)$. 

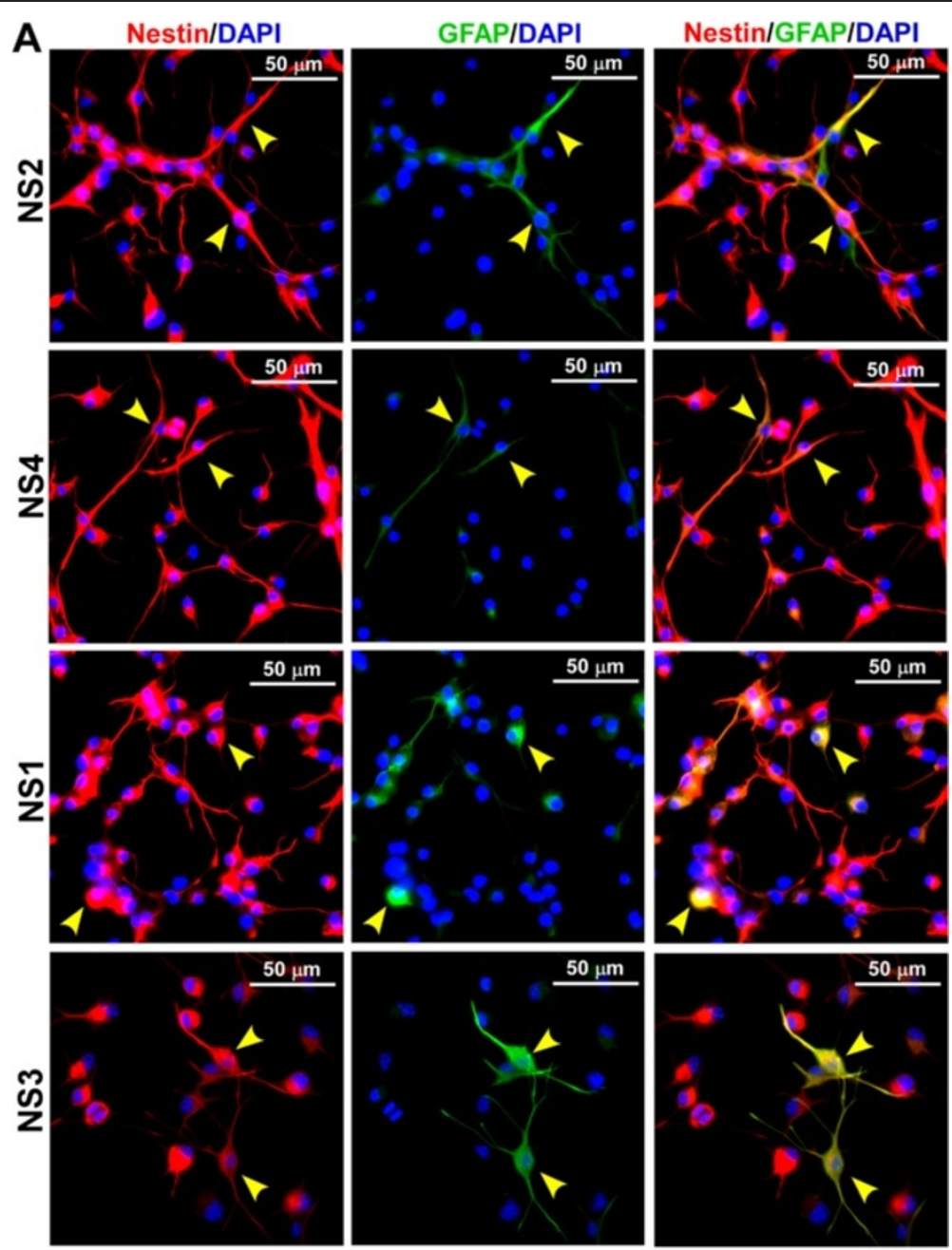

B

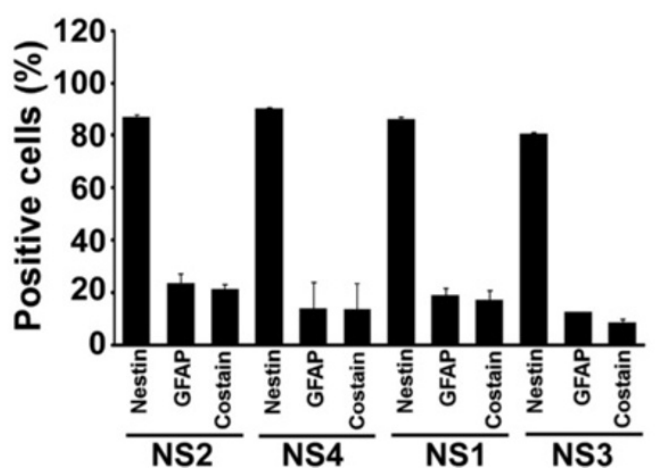

Figure 2 Expression of nestin and glial fibrillary acidic protein (GFAP) in neurosphere cultures. (A) Fixed monolayer culture of neurosphere cultures, cells were immunostained with anti-nestin and anti-GFAP antibodies (for details see materials and methods). All the images are displayed at the same intensity scale. Images show some nestin positive cells are also positive for GFAP (yellow arrowhead). (B) Cell type analysis was performed by counting the cells positive for each marker manually, using ImageJ 1.42q software (NIH). Percent cells positive either for nestin, GFAP or for both markers (co-stain) was plotted as histograms of mean + standard deviation of three independent experiments. No significant difference is found between GFAP stained cell populations among NS1, NS2, NS3 and NS4 lines regardless of the presence of transgenes.

the amplification of 233-bp and 141-bp amplicons specific for huAPPswe and huPSEN1dE9 transcripts respectively in NS1 and NS3 lines but not in NS2 and NS4 lines (Figure 4A). GAPDH mRNA expression was similar in all NS cultures indicating the equal loading of RNA from all NS lines. An RT-minus control PCR on DNase I 

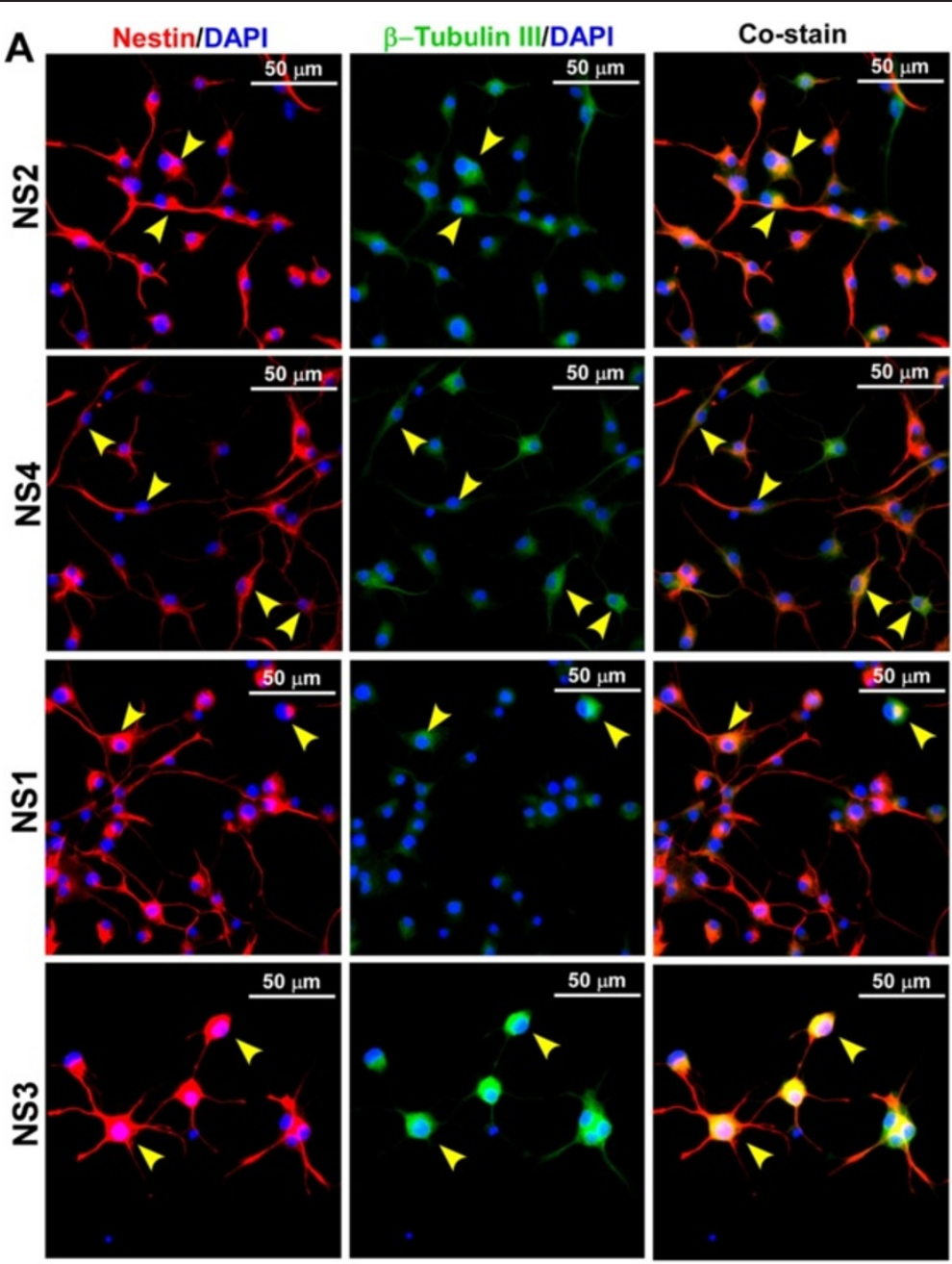

B

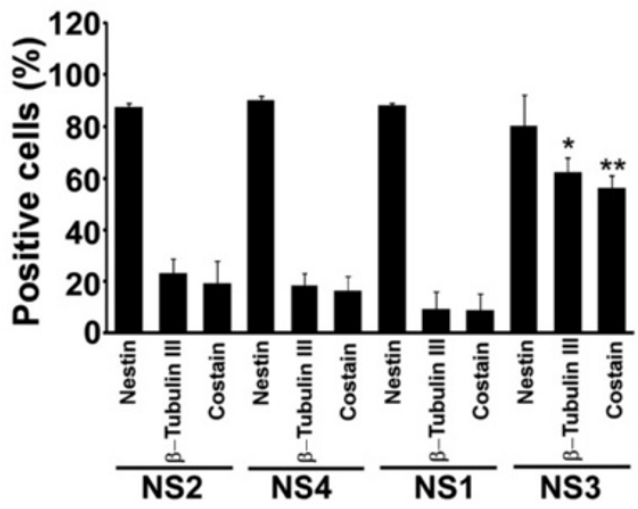

Figure 3 Expression of nestin and $\beta$-tubulin III in NS cultures. (A) Monolayer of cells was cultured as described earlier. Immunostaining with nestin and $\beta$-tubulin III antibodies, image acquisition, analysis and display are similar to Figure 2. Images demonstrate that some cells are positive for both nestin and $\beta$-tubulin III (yellow arrowheads). (B) Percent cells positive either for nestin, $\beta$-tubulin III or for both (co-stain) was plotted as histograms of mean + standard deviation from 6 images from two independent data sets. Significant increase in nestin and $\beta$-tubulin III co-stain cells is observed in NS3 line. *indicates $p \leq 0.05$ when compared with other neurospheres and **indicates $p \leq 0.05$ when compared with NS1 co-stain cells. 

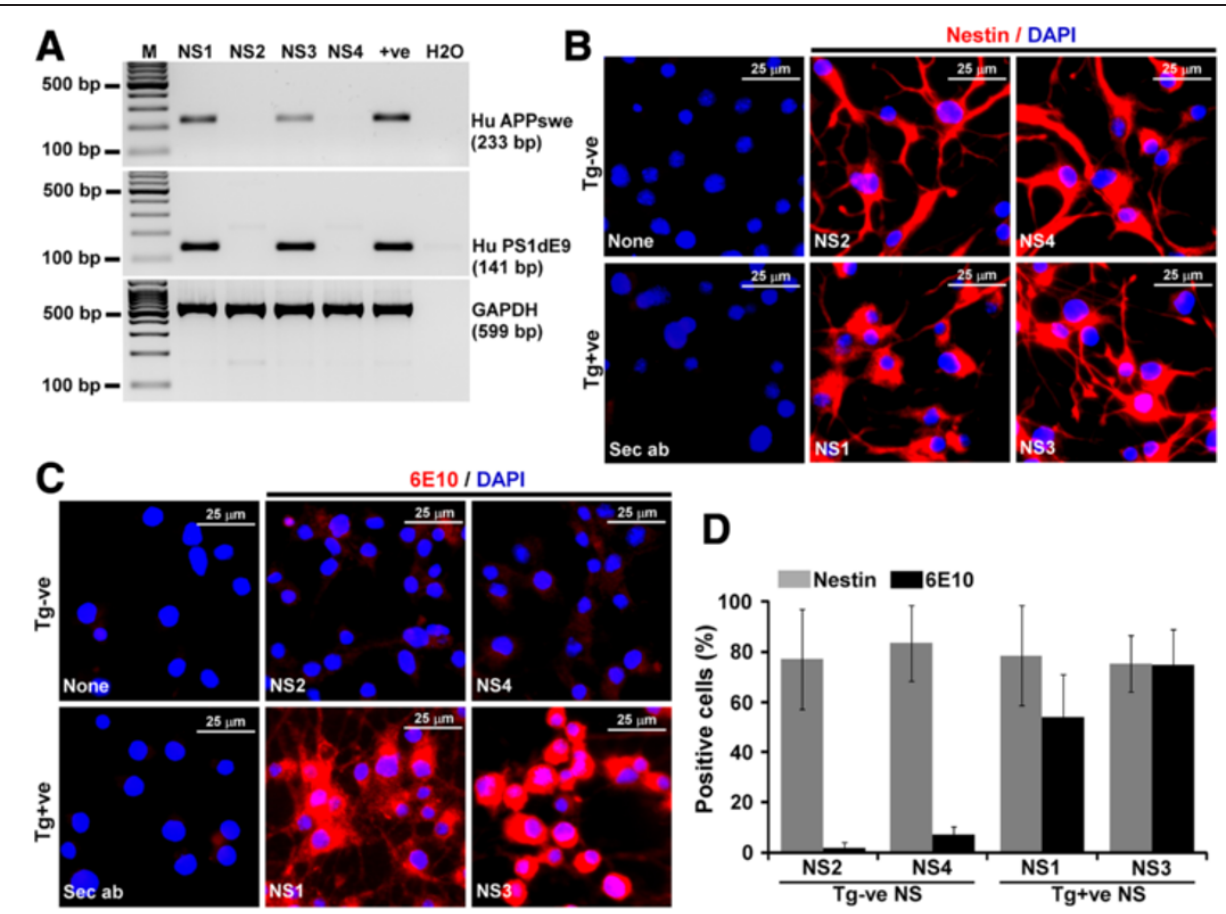

Figure 4 Transgene positive neurosphere cultures transcribe both the transgenes, express humanized APP and co-express nestin. (A) Detection of huAPPswe (233-bp) and huPSEN1dE9 (141-bp) transcripts in neurosphere lines by RT-PCR analysis. A 599-bp GAPDH fragment was amplified to validate equal RNA loading in all NS lines. (B) Immunofluorocytochemistry of nestin shows the majority of cells in all neurosphere lines express nestin. (C) Fluorescence images show expression of huAPPswe protein only in Tg+ve neurospheres using 6 E10 antibody. Nuclei were stained with DAPI. (D) Fluorescence intensity from individual cells was derived and intensity above secondary antibody signal was considered as positive. Percentage of cells positive for each antibody from three independent experiments is demonstrated as histograms of mean \pm standard deviation.

treated RNA from NS lines failed to amplify PSEN1dE9 (data not shown) suggesting the APPswe and PSEN1dE9 amplified products in NS1 and NS3 lines came from mRNA and not from DNA. To study nestin and APP co-expressing cells in Tg+ve NS cultures, we utilized immunofluorocytochemistry along with cell count analysis. Approximately, $77 \pm 20,83 \pm 15,78 \pm 20$ and $75 \pm 11$ percent of total cells analyzed from three independent experiments express nestin in NS2, NS4, NS1 and NS3 cultures respectively (Figure 4B \& D). Immunostaining analysis ( $\mathrm{n}=3$ independent experiments) with $6 \mathrm{E} 10$ antibody showed only $1.8 \pm 2.2,7 \pm 3.3$ in Tg-ve NS2 and NS4 lines respectively but $54 \pm 17.12$ and $75 \pm 13.6$ percent cells positive for APP expression in Tg+ve NS1 and NS3 cultures respectively (Figure 4C \& D). Since nestin as well as APP expression is seen in more than $50 \%$ of total cells in Tg+ve NS cultures, it is postulated that nestin positive cells also express APP protein. Collectively, promoters for both the transgenes are active in neural stem cells and express APP protein in $\mathrm{Tg}+\mathrm{ve}$ NS cultures, a prerequisite condition for its proteolytic processing towards $A \beta$ peptide formation.
Cells in Transgene positive neurosphere lines co-express human APP protein and $\beta$-tubulin III or GFAP

Immunofluorocytochemical analysis of $\beta$-tubulin III expression demonstrates few cells are positive in Tg-ve NS2 and NS4 cultures and as expected, these cells are negative for APP expression. In Tg+ve NS1 and NS3 cultures, $\beta$-tubulin III positive cells co-localize with APP expression (Figure 5A). Cell type analysis of these cells from three independent experiments indicates almost all the $\beta$-tubulin III positive cells in NS1 $(10.3 \pm 5.3 \%)$ and NS3 $(45.4 \pm 6.8 \%)$ cultures also express APP protein (Figure 5B). When cells were co-immunostained with APP and GFAP, the results show $13.01 \pm 2.3 \%$ and $11 \pm$ $4.1 \%$ of total cells express GFAP in Tg-ve NS2 and NS4 cultures, and are not co-stained for APP expression (Figure 6B). In Tg+ve NS cultures, approximately, $14.8 \pm$ $2.4 \%$ and $9.55 \pm 5.5 \%$ cells are positive for GFAP expression in NS1 and NS3 respectively (Figure 6A \& B). Cell type analysis shows that the majority of them also express APP (Figure 6B). Thus, $\beta$-tubulin III +ve neuronal and GFAP + ve astroglial progenitors are present in our NS cultures and express APP protein in $\mathrm{Tg}+\mathrm{ve}$ neurosphere cultures. 

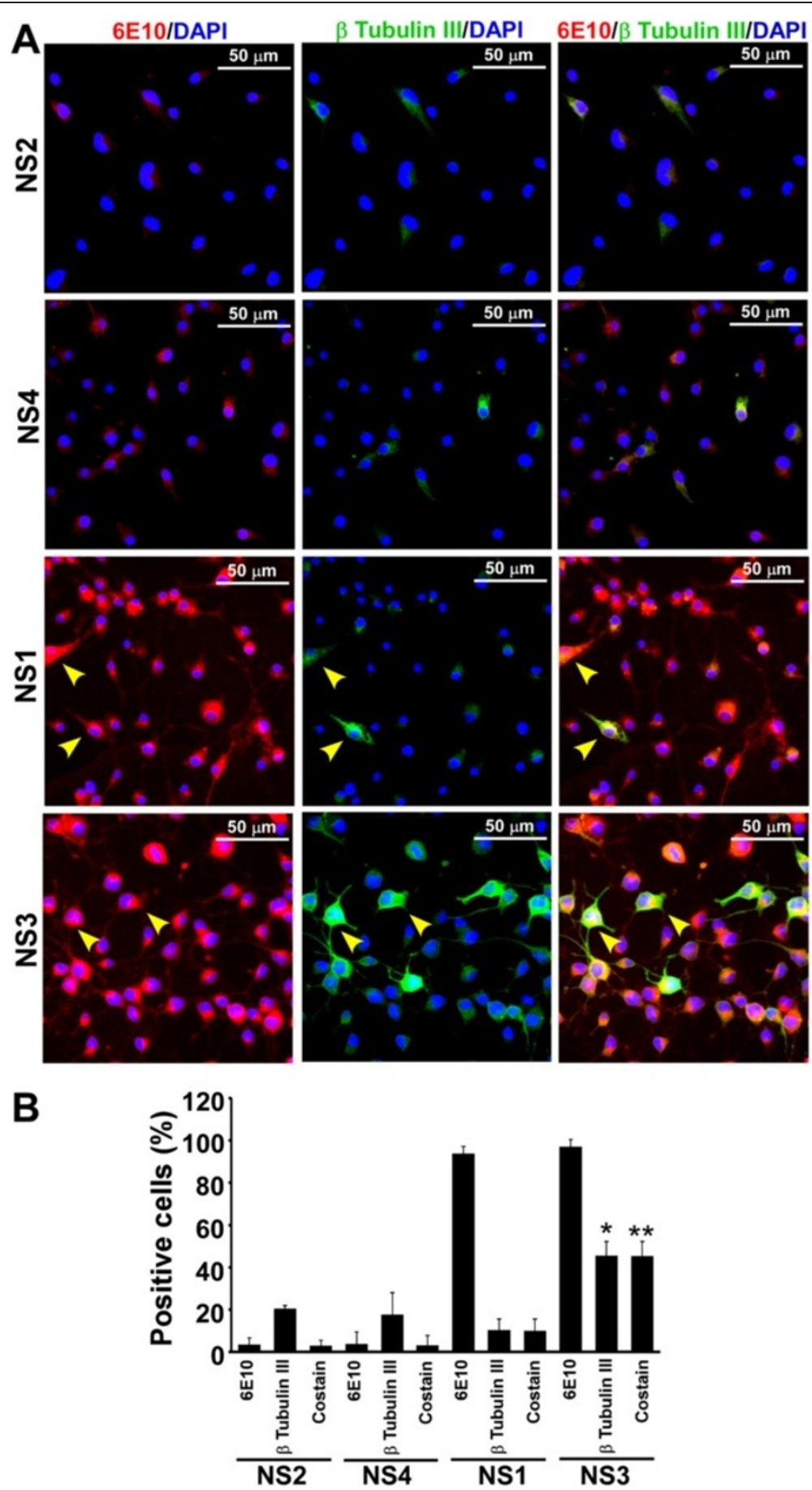

Figure 5 Expression of APP and $\beta$-tubulin III proteins in neurosphere monolayer cultures. (A) Triturated cells from NS cultures were grown on PDL coated optical cover-glass plates or glass coverslips for 3 days in complete media. Immunostaining with 6 E10 (specific for human APP) and $\beta$-tubulin III antibodies, image acquisition, analysis and display are similar to Figure 2. Images demonstrate presence of cells positive for both APP and $\beta$-tubulin III in NS1 and NS3 (yellow arrowheads). (B) Percent cells positive either for APP or $\beta$-tubulin III or both (co-stain) are plotted as histograms of mean + standard deviation from three independent data sets. Significantly more APP and $\beta$-tubulin III co-stained cells are observed in NS3 line. *indicates $p \leq 0.05$ when compared with other neurospheres and **indicates $p \leq 0.05$ when compared with NS1 co-stained cells. 

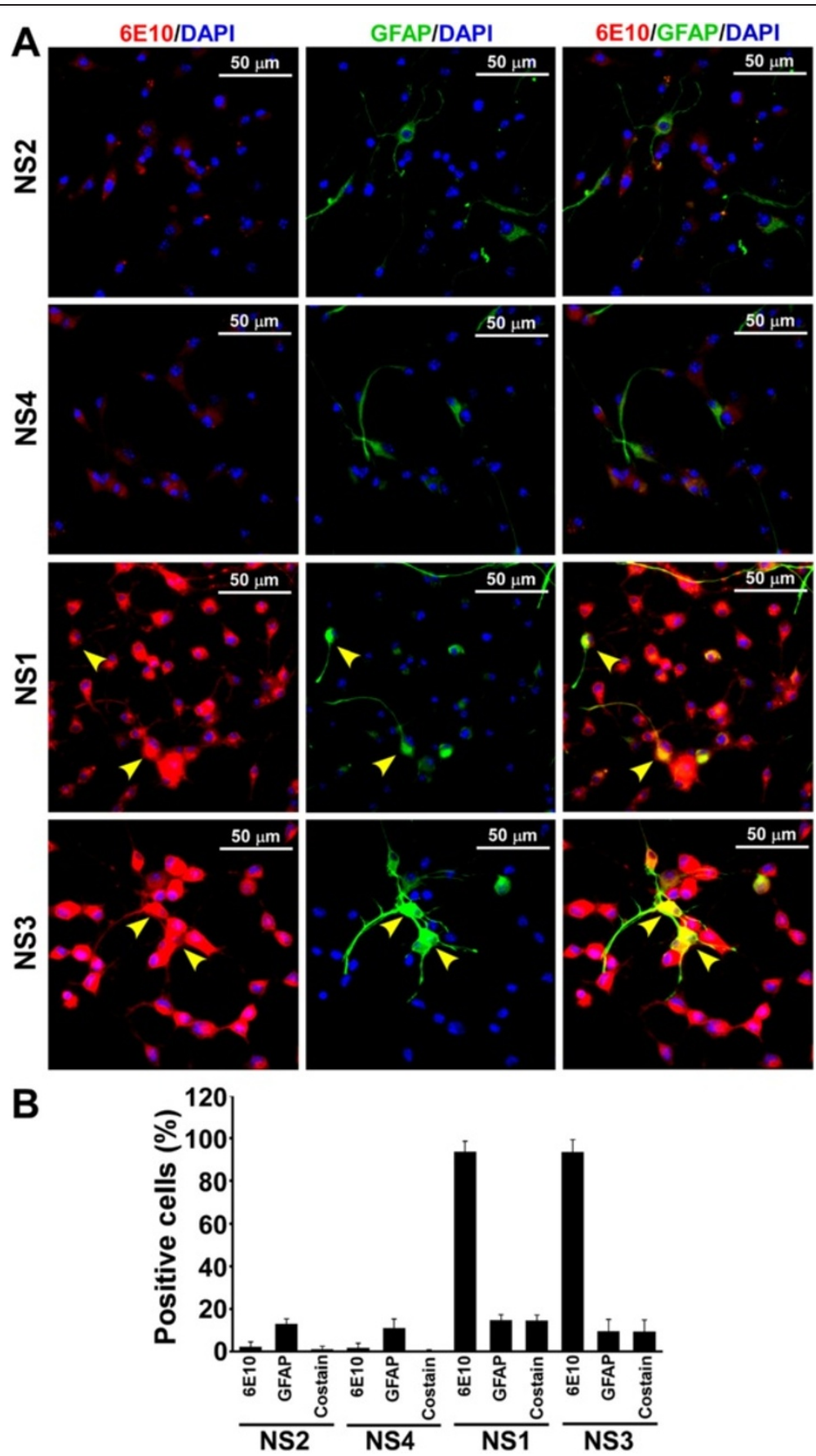

Figure 6 Expression of APP and GFAP proteins in neurosphere monolayer cultures. (A) Immunostaining of APP and GFAP on cell monolayers were performed as described earlier. Images demonstrate that some cells are positive for both APP and GFAP (yellow arrowheads) in Tg+ve NS lines. (B) Percent cells positive either for APP, GFAP or both (co-stain) are plotted as histograms of mean + standard deviation from four independent experiments.

Transgene positive neurosphere lines express full-length APPswe protein and generate amyloid- $\beta$ (A $\beta$ ) monomers and pathogenic oligomers

Western blot analysis of NS lysates from NS1-4 lines with 6E10 antibody clearly demonstrated the expression of full length huAPPswe $(90.2 \mathrm{kDa})$ and its processed peptides in NS1, NS3 and Tg+ve mouse brain homogenate (positive control) but not in NS2, NS4 and Tg-ve mouse brain homogenate (negative control). A fragment close to $12 \mathrm{kDa}$ was seen only in $\mathrm{Tg}+\mathrm{ve}$ NS lines and in $\mathrm{Tg}+\mathrm{ve} \mathrm{MBH}$, which likely represents the C99 fragment (APP $\beta$-carboxy-terminal fragment). Interestingly, additional 
bands ranging from $10.1 \mathrm{kDa}$ to $62.3 \mathrm{kDa}$ were also seen exclusively in $\mathrm{Tg}+\mathrm{ve}$ NS lines and $\mathrm{Tg}+\mathrm{ve} \mathrm{MBH}$. Molecular weight analysis of these bands corresponds to 2 to 14mers of $A \beta$ oligomers (Figure 7). In addition, monomeric $\mathrm{A} \beta$ peptides were detected only in $\mathrm{Tg}+\mathrm{ve}$ but not in $\mathrm{Tg}$-ve NS lysates. However, monomeric and oligomeric A $\beta$ peptides intensities are weaker in $\mathrm{Tg}+\mathrm{ve}$ NS lysates than in $\mathrm{Tg}+\mathrm{ve} \mathrm{MBH}$. It is important to mention here that $\mathrm{Tg}+\mathrm{ve}$ $\mathrm{MBH}$ contains both extracellular and intracellular $\mathrm{A} \beta$ peptides whereas NS lysates contain mostly intracellular A $\beta$ peptides. Collectively, $\mathrm{Tg}+\mathrm{ve}$ NS cultures express APP and its proteolytic peptides including $A \beta$ peptides in monomeric and pathogenic oligomeric forms.

\section{Transgene positive neurosphere cultures secrete large} amount of $A \beta$ peptides into culture media

Since $A \beta$ peptide levels were lower in $\mathrm{Tg}+\mathrm{ve}$ NS lysates than $\mathrm{Tg}+\mathrm{ve} \mathrm{MBH}$ and $\mathrm{A} \beta$ peptides are deposited as senile plaques in the extracellular matrix of $\mathrm{AD}$ brain, we reasoned that most of the $A \beta$ peptides might be secreted into culture media. Western blot analysis of concentrated NS culture supernatants demonstrated the presence of human A $\beta$ peptides only from NS1 and NS3 cultures (Figure 8A). Oligomers (3-9-mer) and large oligomers of A $\beta$ peptides are also seen in NS1 and NS3 culture supernatants (Figure 8A). A longer electrophoresis of the same samples in a separate polyacrylamide gel exhibited the presence of 10 and 12-mer A $\beta$ oligomers in NS1 and NS3 culture supernatants (Figure 8B). Using known amount of $A \beta 42$ peptides as standards, densitometric analysis of monomeric $A \beta$ peptides in NS1 and NS3 culture supernatant was found to be $173 \pm$ $96 \mathrm{ng}$ and $128 \pm 42 \mathrm{ng}$ per milligram of total protein respectively ( $\mathrm{n}=4$ independent experiments) (Figure $8 C$ ). In addition, the densitometric analysis of total oligomeric fractions (ranging from 2-mer to large oligomers) indicated NS1 culture supernatant has approximately 2.5-fold more A $\beta$ oligomeric forms than NS3 culture supernatant (Figure $8 \mathrm{D}$ ). Taken together, $\mathrm{Tg}+\mathrm{ve}$ neurosphere cultures secrete both monomeric and wide range of $A \beta$ oligomeric isoforms, a signature of AD pathology (Lesne et al. 2013).

Next we wanted to resolve monomeric $A \beta$ pool to identify various $A \beta$ peptides secreted into the culture medium. Results showed the $A \beta 40$ and $A \beta 42$ peptides are only produced by $\mathrm{Tg}+\mathrm{ve}$ (NS1 and NS3) but not by Tg-ve (NS2 and NS4) NS lines (Figure 9A). Densitometric analysis of

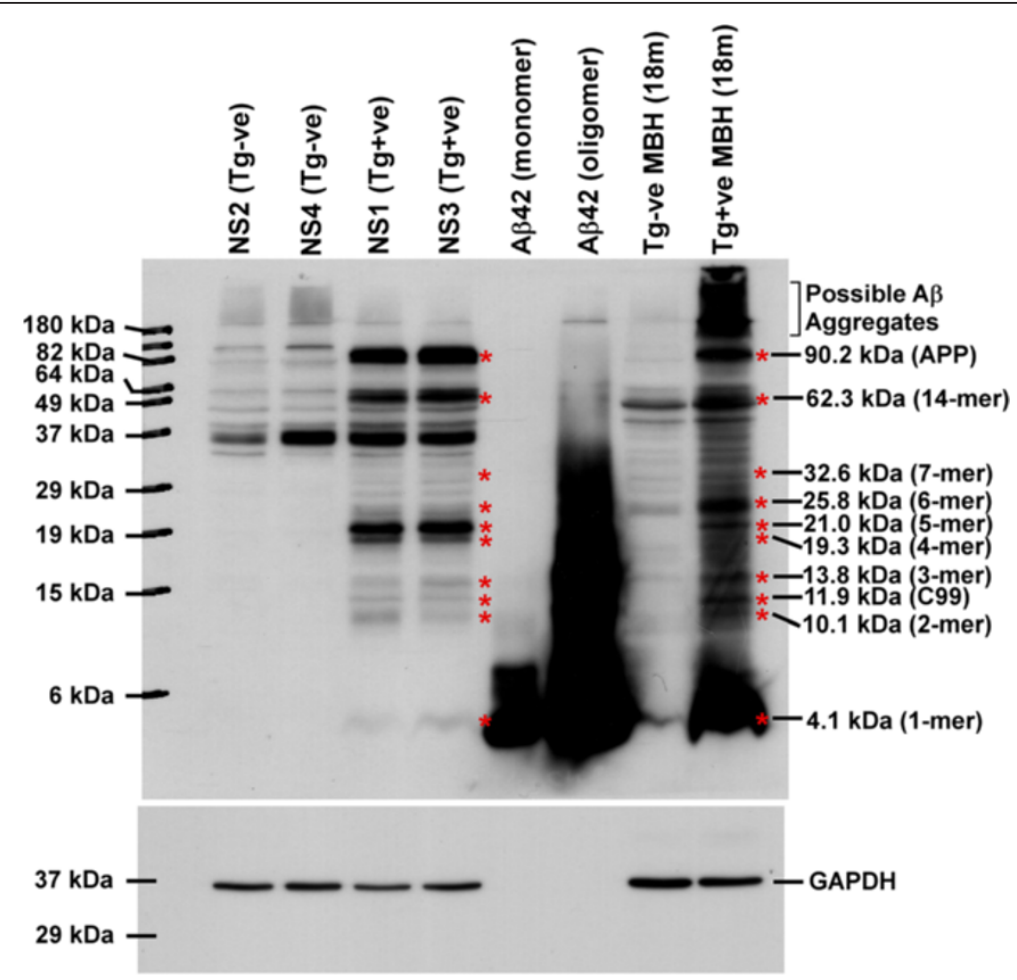

Figure 7 Expression of huAPP and its proteolytic fragments in Tg+ve neurosphere lines. Sixty microgram of total protein from each NS lysate was western blotted onto $0.2 \mu \mathrm{m}$ PVDF membrane and immunoblotted with $6 \mathrm{E} 10$ antibody after HIER. Images clearly indicate the presence of huAPPswe full-length protein only in NS1, NS3 and 18 month $(18 \mathrm{~m})$ old Tg+ve mouse brain homogenate (MBH) but not in NS2, NS4 and $18 \mathrm{~m}$ old Tg-ve MBH. Monomeric and 2 days old oligomeric Aß42 peptides were taken as positive controls. *indicates bands in common between Tg+ve neurosphere lysates and $18 \mathrm{~m}$ old Tg+ve MBH but not present in Tg-ve neurosphere lysates and $18 \mathrm{~m}$ old Tg-ve MBH. Molecular weight analysis indicates these bands could represent A $B$ monomers to various oligomers as mentioned. Membranes were stripped and immunoblotted with GAPDH antibody to verify differences in protein loading. Data represents four independent experiments. 

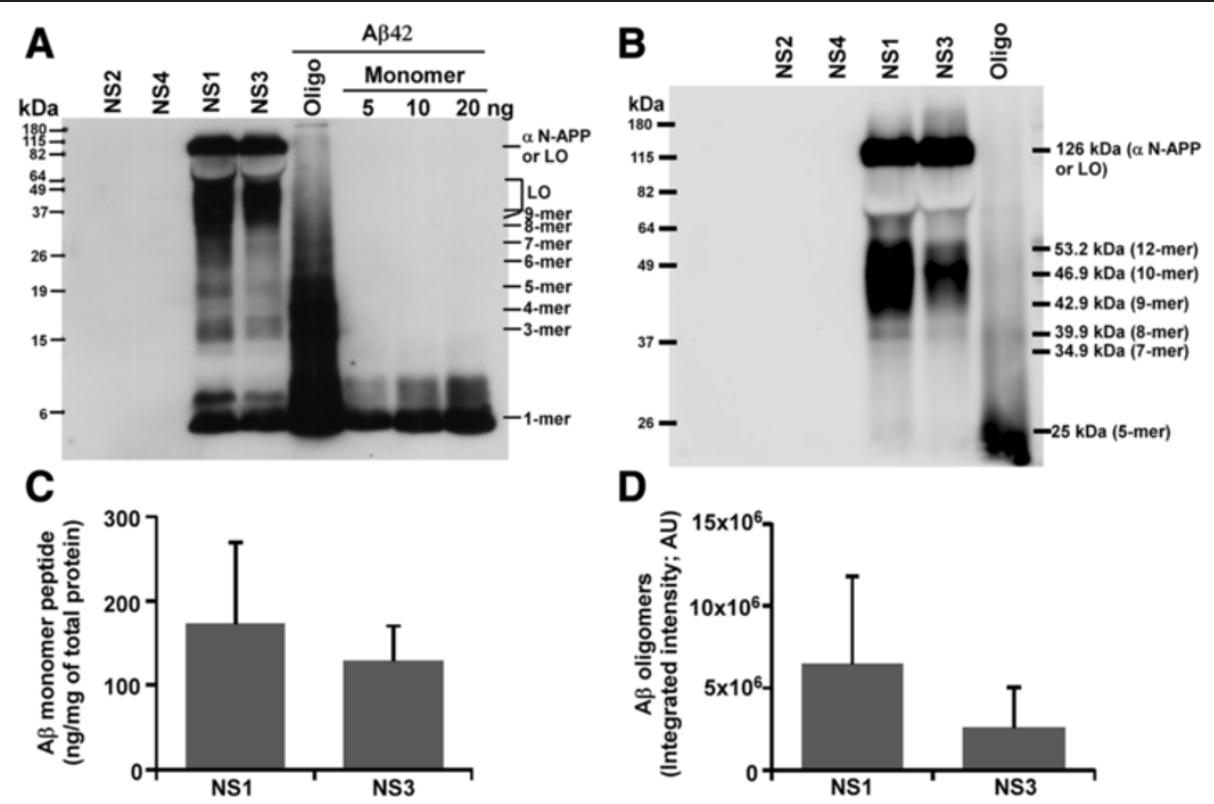

Figure 8 Detection of human $\mathbf{A} \beta$ peptides in neurosphere culture supernatants. (A) Sixty microgram of total protein from 80 to 100 -fold concentrated neurosphere culture supernatant were size fractionated in Tris-Glycine-SDS-PAGE along with monomeric and oligomeric A 42 peptides as positive controls, transferred onto $0.2 \mu \mathrm{m}$ PVDF membrane and immunoblotted with $6 \mathrm{E} 10$ antibody after heat induced epitope retrieval (HIER). Chemiluminescence digital images show the presence of $A \beta$ monomers and various oligomeric A $\beta$ peptides only in Tg+ve but not in Tg-ve neurosphere culture supernatants. Molecular weight analysis of these bands was compatible with the oligomers indicated. (B) A longer electrophoresis of the same samples resolved high molecular weight oligomers as potential A 3 10-mers and 12-mers. (C) Densitometric analysis was used to measure the monomeric A $\beta$ peptides in NS culture supernatants employing known amounts of A $\beta 42$ as standards. (D) Densitometric analysis of $A \beta$ oligomers (2-mer to $64 \mathrm{kDa}$ ) is presented as histograms of mean + standard deviation. Data represents four independent experiments. $L O=$ Large Oligomer.

$A \beta 40$ and $A \beta 42$ bands from four separate experiments indicated $\mathrm{A} \beta 42 / \mathrm{A} \beta 40$ ratio as $0.875 \pm 0.336$ and $0.989 \pm$ 0.487 for NS1 and NS3 respectively (Figure 9C). Similar to our previous result, NS1 culture supernatants contain approximately 2.2 -fold more oligomeric $A \beta$ peptides than NS3 culture supernatants (Figure 9B \& D).

\section{Cells in transgene positive neurosphere lines have intracellular $A \beta$ peptides}

Western blot analysis of NS lysates indicated the presence of intracellular localization of $A \beta$ peptides. To validate intracellular pool of $A \beta$ peptides, we utilized conformation dependent interaction of $A \beta$ peptides with 6E10 antibody. However, 6E10 antibody interacts with full length human APP as well as human A $\beta$ peptides which requires epitope retrieval (Rosen et al. 2010). To dissect the effect of epitope retrieval on full-length APP and $\mathrm{A} \beta$ peptides by $6 \mathrm{E} 10$ antibody, we performed western blot analysis of $\mathrm{Tg}+\mathrm{ve}$ mouse brain homogenate using 6E10 antibody with or without heat induced epitope retrieval (HIER) (Ida et al. 1996). The densitometric analysis of APP, A $\beta$ and GAPDH bands from both the conditions indicates HIER induced increased $A \beta$ signal is 20 -fold higher than HIER induced increased APP signal and 12fold higher than HIER induced increased GAPDH signal
(Additional file 1: Figure S1). Thus, $A \beta$ peptides require more epitope retrieval than full length APP for its interaction with 6E10 antibody. Similarly, formic acid (FA) treatment has been found to be essential for the detection of aggregated intraneuronal $A \beta$ peptides in the brain section of a mouse model of AD (Christensen et al. 2009) suggesting $A \beta$ epitopes are hidden within aggregated $A \beta$ structures. Immunofluorescent staining of adherent cells from NS cultures demonstrated significant higher immunosignal towards $6 \mathrm{E} 10 \mathrm{in} \mathrm{Tg}+\mathrm{ve}$ than $\mathrm{Tg}$-ve NS lines without FA treatment (Figure 10A, upper panel \& 10B). However, after FA treatment, $\mathrm{Tg}+\mathrm{ve}$ cells showed dramatic increased immunosignal over untreated counterparts, whereas, as expected, Tg-ve cells showed marginal increase (Figure 10A, lower panel \& 10B). Thus, increased immunosignal in $\mathrm{Tg}+\mathrm{ve}$ neurosphere cultures to epitope retrieval might represents intracellular monomeric and oligomeric $\mathrm{A} \beta$ peptides.

\section{Accumulation of extracellular and intracellular $A \beta$ peptides within transgenic positive neurospheres}

Since our neurosphere cultures are much slower growers (split 1 to 3 every 30 to 40 days) than cancerous cell lines and neurospheres under most other culture conditions (split 1 to 4 once a week) (Orr et al. 2012), 

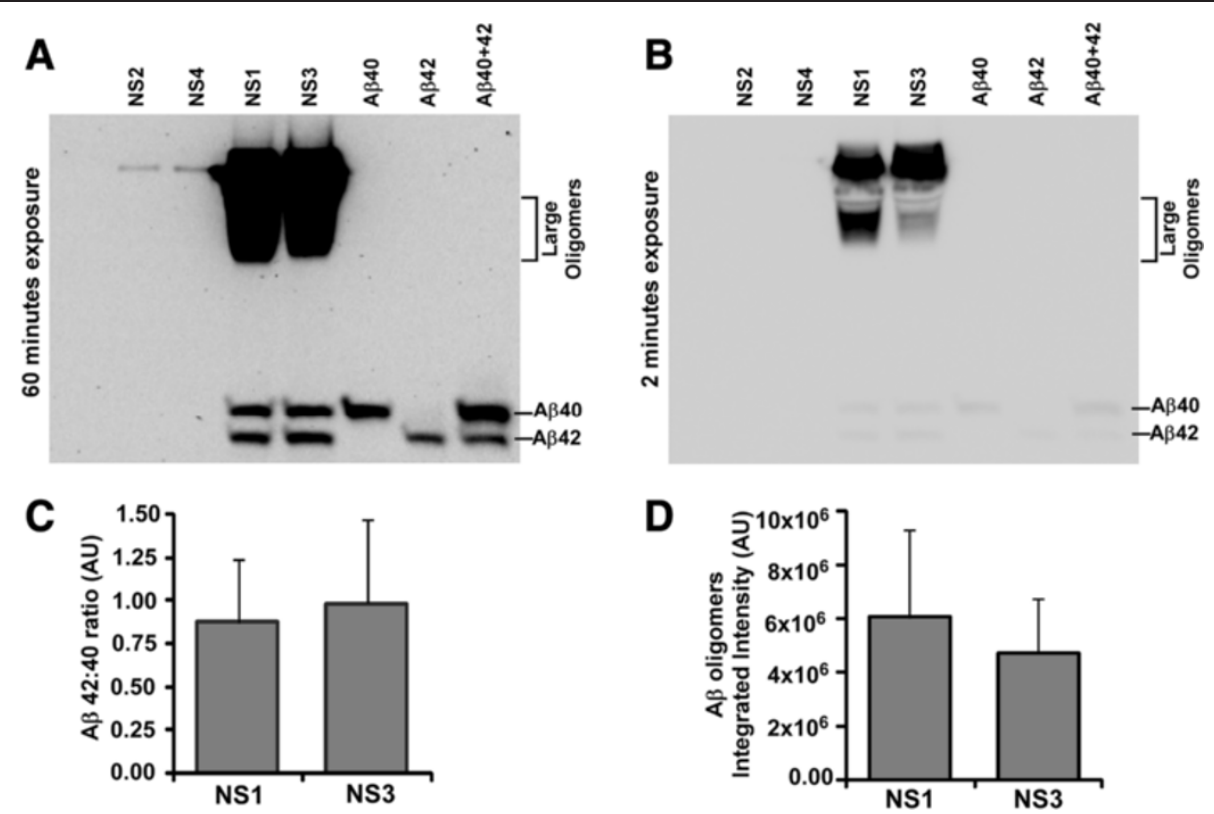

Figure 9 Amyloid- $\beta$ peptides in $\mathbf{T g}+\mathbf{v e}$ neurosphere culture supernatants contain $\mathbf{A} \beta 40$ and $\mathbf{A} \beta 42$ peptides. (A) Sixty microgram of total protein from concentrated neurosphere culture supernatants were size fractionated in 10\% Tris-Bicine-Urea-SDS-PAGE along with 5 ng of monomeric A 340 and $A \beta 42$ peptides, followed by immunoblotting with $6 \mathrm{E} 10$ antibody after HIER. Tg+ve NS1 and NS3 neurosphere culture supernatants contain both $A \beta 40$ and $A \beta 42$ peptides but they are not seen in Tg-ve neurosphere culture supernatants. (B) Images from a shorter exposure show large oligomeric A $\beta$ levels are higher in NS1 than NS3 culture supernatants. (C) Densitometric analysis of A 340 and A 442 peptide bands indicates the ratio of A 42/Aß40 in NS1 and NS3 culture supernatants as $0.875 \pm 0.336$ and $0.989 \pm 0.487$ respectively. (D) Densitometric analysis of large $A \beta$ oligomers is presented as histogram of mean + standard deviation from four separate experiments.

we speculated $\mathrm{A} \beta$ peptides might aggregate within $\mathrm{Tg}+\mathrm{ve}$ neurospheres. NS sections immunostained with $6 \mathrm{E} 10$ antibody and with or without 70\% FA treatment showed significant increased immunoreactivity in $\mathrm{Tg}+\mathrm{ve}$ than Tg-ve NS lines (ANOVA, non parametric, $\mathrm{H}=817.827$, $\mathrm{P}<0.001, \mathrm{n}=6$ neurosphere sections) (Figure 11A \& B). Moreover, FA treated Tg+ve NS sections, demonstrated significant increased immunoreactivity over untreated counterparts (Figure 11A \& B). Immunosignals of puncta were seen within neurosphere sections but outside cellular structures raising the possibility of extracellular aggregation of amyloid- $\beta$ peptides. In order to address the specificity of 6E10 antibody, NS sections were immunostained with an antibody specific for human A $\beta 42$. Tg+ve NS sections exhibited very high immunostaining in FA treated sections in comparison to untreated $\mathrm{Tg}+\mathrm{ve}$ NS sections (Figure 11C \& D). Small aggregates were seen outside the cellular bodies in FA treated $\mathrm{Tg}+\mathrm{ve}$ NS sections (Figure $11 \mathrm{C}$, middle and right panel, red arrowheads). In addition, aggregates of $A \beta 42$ immunosignal in the form of puncta are also seen within the cells of FA treated $\mathrm{Tg}+\mathrm{ve}$ NS sections (Figure 11C, right panel, purple arrowheads). Collectively, our results indicate intracellular and extracellular aggregation of $\mathrm{A} \beta$ peptides in $\mathrm{Tg}+\mathrm{ve}$ neurospheres lines.

\section{Discussion}

In this study, we report a novel way to model the genetics of familial Alzheimer's disease (FAD) using mouse neurosphere cultures expressing APPswe and PSEN1dE9 mutations of FAD. Using these culture systems we observed the synthesis, secretion, oligomerization and aggregation of human beta amyloid peptides (A 340 and $A \beta 42$ ) better than existing cellular models of $A D$ and comparable to transgenic mouse models of AD (Citron et al. 1997; Oakley et al. 2006).

Several cell culture-based systems from human or rodent, primary or cell lines of neuronal or non-neuronal have been reported. Primary neuronal cultures were preferred over transformed cell lines for two major reasons a) APP expression was thought to be restricted to mature neurons, and b) genomic instability in cancerous cell lines. Although, primary neuronal cultures from transgenic animal models for $A D$ produced both $A \beta 40$ and $A \beta 42$ peptides but survived only for 12 days (Trinchese et al. 2004) or up to 20 weeks (Yun et al. 2007). Recently, induced pluripotent stem cells (iPSCs) derived from fibroblast of FAD patients have been used to model amyloid- $\beta$ genesis in vitro (Yagi et al. 2011). A similar model was developed using fibroblasts from two sporadic and two familial AD patients. Both the FAD lines and one of two lines from 


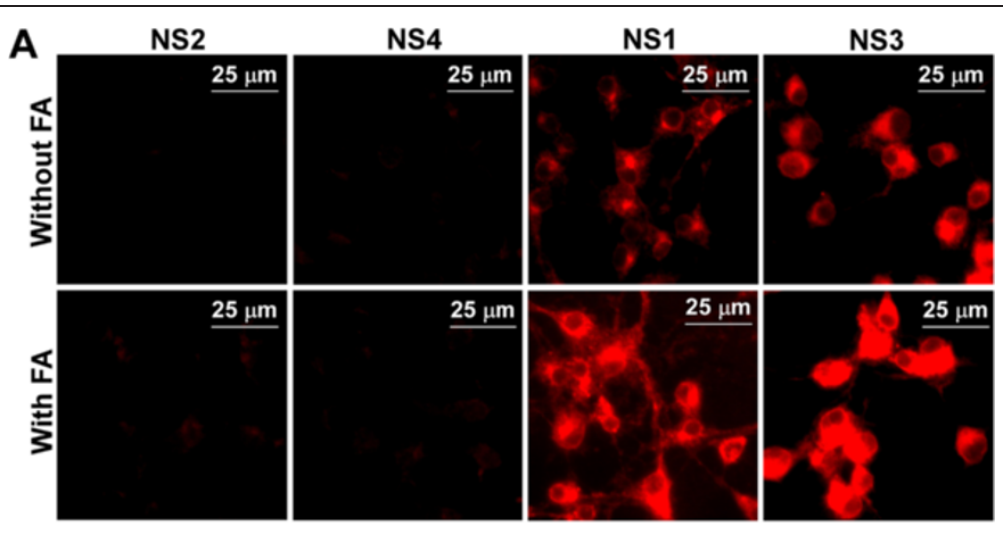

B

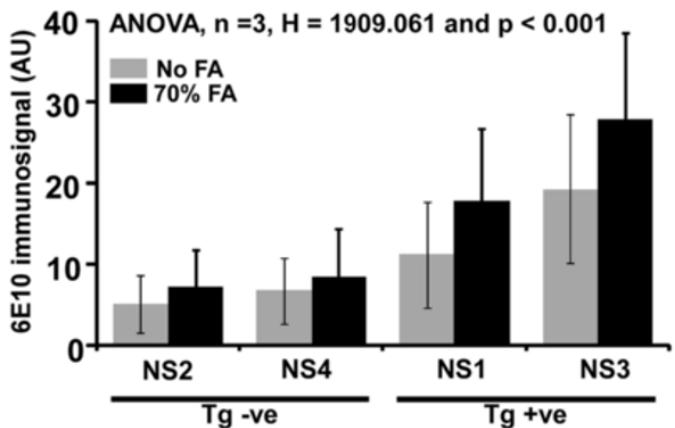

Figure 10 Detection of intracellular $\mathbf{A} \boldsymbol{\beta}$ peptides by CDIC. (A) Fixed and permeabilized adherent cells from neurosphere cultures were either treated with formic acid (FA) or left untreated followed by immunostaining with 6E10 antibody. Detection was done using Alexa 594 labeled secondary antibody. (B) Quantification of fluorescence intensity indicates that Tg+ve NS lines show significant increased signal over Tg-ve lines in both the treatments. FA treatment significantly increased signal in Tg+ve NS lines (NS1 and NS3) compared to non-treated counterparts suggesting the possible presence of intracellular $A \beta$ peptides (non-parametric one-way ANOVA, $n=3, H=1909.061$ and $p<0.001$ ).

patients with sporadic disease show increased A $\beta 40$ levels over wild type cells (Israel et al. 2012). However, the level of $A \beta 42$ is not reported, which increases over $A \beta 40$ in $A D$ patients. In addition, these models utilize transduction of fibroblast with retroviruses encoding OCT4, SOX2, KLF4 and $c-M Y C$, which are by and large cancerous and form teratomas (Israel et al. 2012). Nevertheless, the advantage of studying patients-derived lines is to determine the influence of varied genetic backgrounds on AD pathology in vitro. However, in this report, the role of FAD mutations on mouse neurosphere cultures can be studied on a defined genetic background and these cultures grow continuously for more than 15 passages (at least a year). Thus, our neurosphere cultures offer the advantage of both cell lines and primary cultures.

Unlike iPSC-based culture systems, none of the primary and cancerous cellular model of AD addressed more than one cell type. In this study, neurosphere cultures contain a high percentage of nestin positive CNS stem cells/progenitor cells as reported earlier (Lendahl et al. 1990). Some nestin positive cells express either GFAP (marker for astrocytes) or $\beta$-tubulin III (a marker for young and mature neuron) proteins. Cells co-expressing nestin and GFAP has been reported as astroglial progenitor cells
(Wei et al. 2002; Draberova et al. 2008). Radial glia cells of human fetal telencephalon and post-natal rat also express GFAP and nestin along with GLAST (Zecevic 2004; Gubert et al. 2009). Thus, nestin and GFAP co-expressing cells in neurosphere cultures suggests the presence of astroglial progenitor and/or radial glia cells. However, we have not tested other markers of radial glial cells such as GLAST and BLBP. Furthermore, co-expression of nestin and neuronal markers, NeuN (Wei et al. 2002) and $\beta$-tubulin III (Draberova et al. 2008) has been reported as an indicator of neuronal precursor cells. Therefore, neurosphere cultures in this study contain CNS stem, glial progenitor and neuronal progenitor cells, which may provide additional options to study a variety of differentiated brain cells in the future. Differentiation of our neurosphere cultures produce $\mathrm{MAP}^{+}$and $\beta$-tubulin $\mathrm{III}^{+}$neurons and $\mathrm{GFAP}^{+}$astrocytes without nestin expression (data not shown).

It has been reported that, $A \beta$ peptides are derived from the proteolytic cleavage of APP. Our results from neurosphere lysates (Figure 7) show the expression of full-length humanized APPswe transgene protein and its processed peptides in $\mathrm{Tg}+\mathrm{ve}$ but not in Tg-ve NS cultures. Presence of C99 peptides suggests the expression 


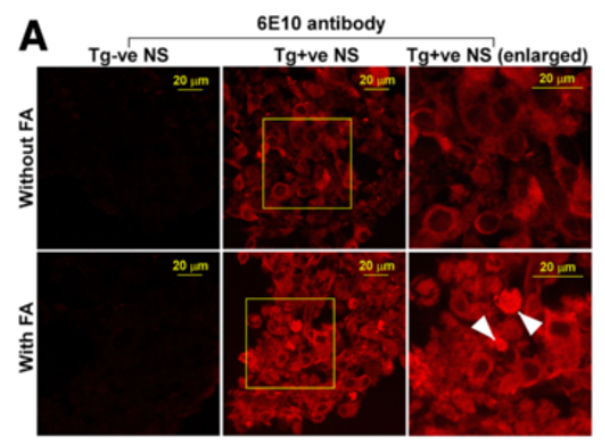

\section{B}

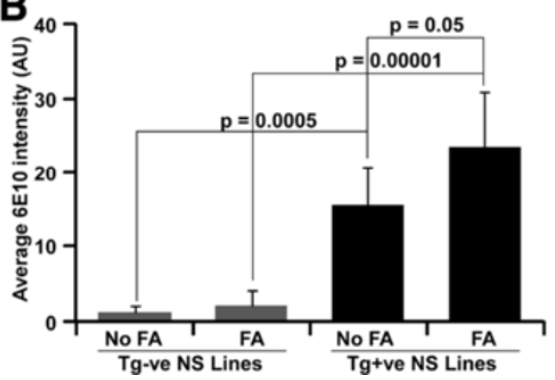

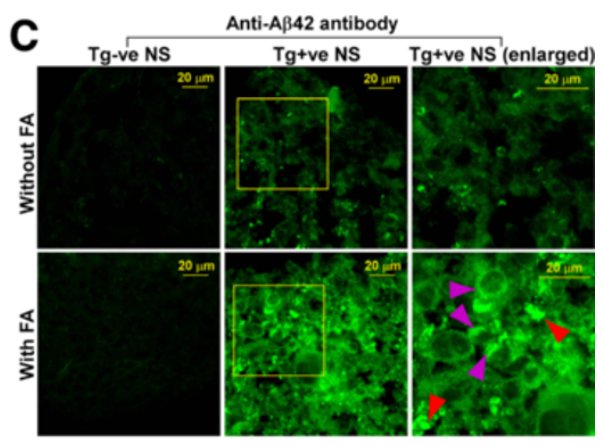

D

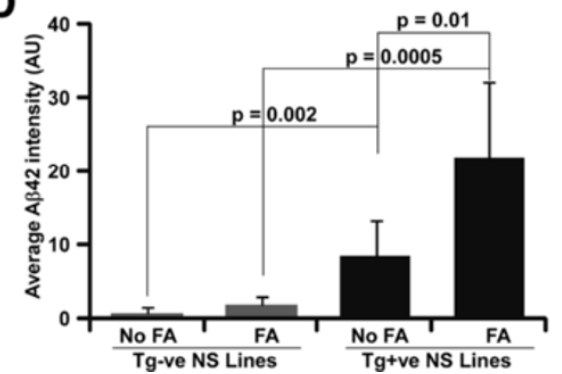

Figure 11 Detection of $\mathbf{A} \boldsymbol{\beta}$ peptides within neurospheres by CDIC. (A) Neurosphere sections (10 $\mu \mathrm{m}$ thick) were either treated with FA or left untreated, then immunostained with 6E10 antibody. Confocal images were captured using similar exposure settings and displayed with similar intensity scale. White arrowheads indicate the presence of puncta within neurosphere sections. (B) Fluorescence intensities were measured and are plotted as histograms of mean + SD of six neurospheres sections. (C) Neurosphere sections were also immunostained with an anti-A 342 antibody with similar pretreatments. Red and purple arrowheads indicate the presence of puncta outside and within the cells respectively. (D) Intensity of A 42 fluorescence was measured from six independent neurosphere sections and the mean + SD is plotted as histograms. Student's $T$-test was performed. $p$ value $\leq 0.05$ indicate significant difference between the groups.

of $\beta$-secretase in mouse CNS stem cells and its proteolytic activity on transgene-encoded APPswe protein as reported earlier (Vassar et al. 1999). Presence of A $\beta$ peptides also suggests the proteolysis of APP by $\gamma$-secretase of which PSEN1 is one of the components. Thus, neurosphere culture system has necessary cellular machineries to produce $A \beta$ peptides from APP.

$A \beta$ peptides are the major insoluble component of the senile plaques in $\mathrm{AD}$ and are elevated in $\mathrm{AD}$ brain. In $\mathrm{AD}$ patients, total $\mathrm{A} \beta$ load ranged from $7.8 \mathrm{ng} / \mathrm{mg}$ (Wang et al. 1999), 39.824 ng/mg (Ingelsson et al. 2004) to $171 \mathrm{ng} / \mathrm{mg}$ (Lue et al. 1999) of total brain proteins. Primary hippocampal cell cultures expressing human APP and PSEN1 mutations produced only $3.28 \mathrm{ng}$ of $\mathrm{A} \beta$ peptides from each milligram of total culture supernatant proteins (Trinchese et al. 2004). Purified neurons differentiated from iPSC lines isolated from two FAD patients and one of two sporadic patients secreted only $0.3 \mathrm{ng}$ of $\mathrm{A} \beta 40 / \mathrm{mg}$ of lysate (Israel et al. 2012). Transgenic mice expressing five familial Alzheimer's disease mutations (5XFAD; Tg6799) have been reported to produce A $\beta$ peptides approximately $205 \mathrm{ng} / \mathrm{mg}$ and $160 \mathrm{ng} / \mathrm{mg}$ of total brain lysate protein in female and male mice respectively at 12 months of age (Oakley et al. 2006). In present study, $\mathrm{Tg}+\mathrm{ve}$ neurosphere cultures produce monomeric A $\beta$ peptides of $172 \pm 96 \mathrm{ng} / \mathrm{mg}$ and $128 \pm$
$42 \mathrm{ng} / \mathrm{mg}$ of total culture supernatant proteins in NS1 and NS3 neurosphere cultures respectively. Taken together, these neurosphere cultures secrete extracellular $A \beta$ peptides comparable to the concentration of $\mathrm{A} \beta$ peptides in human AD brain, 5XFAD mouse brain and much higher level than iPSC and other cellular models of AD.

$\mathrm{A} \beta 40$ and $\mathrm{A} \beta 42$ are most prevalent $\mathrm{A} \beta$ peptides in $\mathrm{AD}$. Tg+ve neurosphere lines secrete both $\mathrm{A} \beta 40$ and A $\beta 42$ with $A \beta 40$ amount more than $A \beta 42$. A similar observation has been made in blood plasma and cerebrospinal fluid from AD patients (Bibl et al. 2006) suggesting $A \beta 40$ might be produced more or secreted more efficiently than $A \beta 42$. It has been reported that pathogenic $A \beta 40$ and $A \beta 42$ peptides are produced by neurons, astrocytes (LeBlanc et al. 1997) and oligodendrocytes (Skaper et al. 2009) in AD indicating the expression of APP not only restricted to neurons but also in astrocytes and oligodendrocytes. Furthermore, earlier reports also suggest physiological expression of APP in two-cell embryo, preimplanted and postimplanted embryos, and in the developing neural tube where early neural stem cells are formed (Fisher et al. 1991). Therefore, neural stem/ progenitor cells of developing and adult brain might be contributing $A \beta$ peptides to total brain $A \beta$ load in $\mathrm{AD}$ patients as well as in the animal model of $\mathrm{AD}$. In 
continuation to this, mouse prion protein is also expressed in neuron, astrocytes, oligodendrocytes and neural stem cells of adult brain. Therefore, utilization of Prnp promoter to express FAD genes is a better choice not only for neurons but other brain cells including neural stem/progenitor cells.

A $\beta 42 / A \beta 40$ ratio has been found to be higher in cells or mice expressing both APP and mutant PSEN1 gene than expressing wild type APP alone (Borchelt et al. 1996b; Tomita et al. 1997). In addition, AD patients with PSEN1/ PSEN2-linked mutations exhibited increased A $\beta 42 / \mathrm{A} \beta 40$ ratio than unaffected individuals and this elevated ratio is considered as a pathological feature of AD (Scheuner et al. 1996). A $\beta 42 / A \beta 40$ ratio in the culture supernatant of primary hippocampal neurons isolated from mice expressing both human APP mutations (K670N: M671L) and human PSEN1 mutation (M146L) is 0.302 (Trinchese et al. 2004). Differentiated neurons from iPSC-based model of FAD patients harboring a mutation in PSEN1 (A246E) or PSEN2 (N141I) genes exhibit $\mathrm{A} \beta 42 / \mathrm{A} \beta 40$ ratio as 0.2 (Yagi et al. 2011). Mice expressing APPswe and PSEN1dE9 mutations (similar to present model) exhibited $A \beta 42 / A \beta 40$ ratio of 1.2 (Jankowsky et al. 2004). A $\beta 42 / A \beta 40$ ratio in 5XFAD mouse model of $\mathrm{AD}$, have been found to be 1.8 in females and 2.75 in males (Oakley et al. 2006). Such high A $342 /$ A $\beta 40$ ratio has been associated with the neurodegeneration seen in this mouse model of $\mathrm{AD}$ independent of tauopathy indicating high $\mathrm{A} \beta 42 / \mathrm{A} \beta 40$ ratio is an important parameter in modeling beta amyloid pathology of $\mathrm{AD}$ in vitro. In this study, we demonstrated $A \beta 42 / A \beta 40$ ratio of $0.875 \pm 0.336$ and $0.989 \pm 0.487$ in NS1 and NS3 culture supernatants respectively. To our knowledge, there is no other cellular model of $A D$ available with such a high $A \beta 42 / A \beta 40$ ratio.

Oligomerization of $\mathrm{A} \beta$ peptides has been reported in Tg2576 mouse brain homogenates and their contribution to cognitive deficits independent of plaque load or neuronal loss, suggesting one or more oligomeric forms of $A \beta$ peptides are pathogenic (Cheng et al. 2007; Cleary et al. 2005; Lesne et al. 2006, 2013). In this study, we observed oligomers of $A \beta$ peptides ranging from 2-mer to 14 -mer in $\mathrm{Tg}+$ ve but not in Tg-ve NS lysates and 212 -mer in $\mathrm{Tg}+\mathrm{ve}$ culture supernatants. Our results also demonstrate the presence of $A \beta-12$ mer $(A \beta * 56)$ peptides in Tg+ve NS culture supernatants. Very recently $A \beta$ trimers, which are thought to be the fundamental amyloid$\beta$ assembly unit of $A \beta^{*} 56$, have been reported in young AD mice as well as in 10 years old children (Lesne et al. 2013). In this report we have also observed the presence of both $A \beta$ trimers and $A \beta * 56$ peptides in $\mathrm{Tg}+\mathrm{ve}$ neurosphere cultures. Therefore, we want to speculate that the pathogenic $A \beta$ production and oligomerization might be happening inside and outside the cells and even in CNS stem or progenitor cells during the early stage of life in AD patients.
Furthermore, presence of $\mathrm{A} \beta$ peptides in $\mathrm{Tg}+\mathrm{ve} \mathrm{NS}$ lysates suggest the presence of intracellular $A \beta$ peptides which is well supported by the results from conformation dependent immunocytochemistry on cells and NS sections. Intraneuronal accumulation of $\mathrm{A} \beta$ peptide has been associated with cellular pathology related to cognitive malfunction in AD brain (Takahashi et al. 2002; Walsh et al. 2000) and in the brain from mouse models of AD (Eimer and Vassar 2013; Oddo et al. 2006; Wirths et al. 2001; Youmans et al. 2012). Neurotoxic effect (Deshpande et al. 2006) and synaptotoxic effect (Walsh et al. 2002) of oligomeric forms of $A \beta$ have also been reported. Our neurosphere cultures continued to grow and showed no sign of cytotoxicity. This could be due to continuous addition of mitotic factors like EGF, FGF and LIF in the culture medium. Similar to our results, no difference in population doubling was observed between wild type and Tg2576 derived secondary neurospheres, equivalent to passage 1 in this study (Baldassarro et al. 2013).

In addition, the amount of $\mathrm{A} \beta$ monomers and oligomers in NS1 is greater than in NS3 culture supernatant in all experiments. We determined that NS1 neurosphere line is female and NS3 is male (for genotyping result, see Additional file 2: Figure S2). It has been shown that female APP/PSEN1 mice build up more amyloid deposits than age matched male mice (Wang et al. 2003; Sierksma et al. 2013). Epidemiological studies also suggest an increased risk for $\mathrm{AD}$ among females compared to age-matched males (Andersen et al. 1999). Collectively, our neurosphere culture manifested higher $A \beta$ load, high $A \beta 42 / A \beta 40$ ratio and gender bias towards $A \beta$ synthesis and oligomerization, which parallels the situation in AD patients and in animal models that express APPswe and PSEN1dE9 mutations.

The effect of $A \beta$ peptides on neural progenitors cells (NPC) is controversial. Proliferation and survival of NPC in the dentate gyrus of the hippocampus was reduced in mice transgenic for FAD mutant $A P P$. Reduced neuronal cell survival was seen after $A \beta$ treatment of cultured human and rodent NPC (Haughey et al. 2002). Uchida et al. have also reported acceleration of differentiation followed by death in $\mathrm{A} \beta$ treated neural stem/progenitor cells (Uchida et al. 2000). In contrast to these reports, increased hippocampal neurogenesis in $\mathrm{AD}$ patients and $\mathrm{A} \beta$ treated neural stem cell cultures from striatum and hippocampus have been reported (Jin et al. 2004; LopezToledano and Shelanski 2004). Most of these reports employed exogenous $A \beta$ peptides treatments. However, our neurosphere cultures secrete $A \beta$ peptides endogenously, ranging from monomeric to various pathogenic oligomeric forms. Whether CNS stem/progenitor cellsenriched neurosphere cultures are affected by being bathed in $A \beta$ peptides is not known. Our future studies will address such questions using these $A \beta$ peptide producing NS cultures. 


\section{Conclusion}

Our results for the first time report that CNS stem/progenitor cell-enriched neurosphere cultures express majorities of the $A \beta$ peptide pathologies that are seen in $\mathrm{AD}$ patients and animal models of $\mathrm{AD}$. The advantages our neurosphere cultures offer over existing cellular models are 1) these cultures offer both primary and cancerous cell benefits, and contain CNS stem/progenitor like cells, which can differentiate towards mature brain cells like neurons and astrocytes that are not possible in transformed cell lines, 2) synthesize and secrete both $A \beta$ peptides, 3) demonstrate high $\mathrm{A} \beta 42 / \mathrm{A} \beta 40$ ratio, 4) produce pathogenic $A \beta$ peptide oligomerization (including toxic $A \beta$ 12-mer; $A \beta^{*} 56$ peptide) at a level comparable to the animal models of $\mathrm{AD}$ and much higher than existing cellular models of AD, including iPSC based models of $\mathrm{AD}$ and 5) demonstrate intracellular and extracellular aggregation of $A \beta$ peptides. Having such strong $A \beta$ peptide pathologies, differentiated cells from these cultures in future will advance our understanding on cellular and molecular changes in response to endogenously produced $A \beta$ peptides and possible therapeutic studies to decrease beta amyloid synthesis and aggregation within cells.

\section{Additional files}

Additional file 1: Figure S1. Effect of heat induced epitope retrieval (HIER) on APP, GAPDH and A $\beta$ peptides. (A) Sixty $\mu g$ of total protein from a $\mathrm{Tg}+\mathrm{ve}$ and $\mathrm{Tg}$-ve mouse brain homogenate was size fractionated in $16 \%$ Tris-Glycine-SDS-PAGE along with 25 ng of Aß42 monomeric peptides. Proteins were transferred onto $0.2 \mu \mathrm{m}$ nitrocellulose membrane and immunoblotted with 6 E10 antibody with or without HIER. Digital images were captured using a ChemiDoc XRS ${ }^{+}$gel doc system (BIO-RAD, USA). Images from blots with or without HIER treatment are displayed with identical image intensity scale. After the completion of imaging, the blots were stripped and immunoblotted with an antibody specific for GAPDH. (B) Densitometric analysis of bands corresponding to APP (full length), $A \beta$ monomers and GAPDH were made using ImageLab (version 3.0) software. Results indicate HIER increased the APP, GAPDH and A $\beta 42$ signal by $5.57,10.38$ and 120.39 fold respectively than without HIER suggesting $A \beta$ peptides require HIER treatment approximately 21 -fold more than APP and 12-fold more than GAPDH. HMW = High molecular weight, $F L=$ full length.

Additional file 2: Figure S2. Detection of male specific gene, SRY by polymerase chain reaction (PCR). Genomic DNA was isolated from neurosphere cultures and also from a male mouse. A DNA PCR was used to amplify SRY gene (specific for maleness in mouse) using forward primer as 5'-AGGCACAAGTTGGCCCAGCA-3' and reverse primer as 5'TGTGGGTTCCTGTCCCACTGCA-3'. Result indicates a band of 269 bp was amplified from the genomic DNA of NS3 and a male mouse but not from NS2, NS4 and NS1. Thus, NS3 neurosphere is a male neurosphere whereas NS1, NS2 and NS4 are female neurospheres. Mo = Mouse.

\section{Abbreviations}

AD: Alzheimer's disease; FAD: Familial Alzheimer's disease; APP: Amyloid precursor protein; PSEN: Presenilin; A $\beta$ : Amyloid beta; CNS: Central nervous system; NPC: Neural progenitors cells; MBH: Mouse brain homogenate; CDIC: Conformation dependent immunocytochemistry; HIER: Heat induced epitope retrieval; FA: Formic acid; NS: Neurosphere; Tg: Transgenic.

\section{Competing interest}

The authors declare that they have no competing interests.

\section{Authors' contributions}

Conceived and designed the experiment: RKG and GAC. Performed the experiment: PSG, HS and RKG. Analyzed the data: PSG. and RKG. All authors discussed the data and the manuscript. RKG. and GAC. wrote the manuscript. All authors read and approved the final manuscript.

\section{Acknowledgements}

We thank the founding director of National Brain Research Centre, Prof. Vijayalakshmi Ravindranath for providing B6C3-Tg(APPswe,PSEN1dE9)85Dbo/J mice. Authors also thank Dr. Deborah E. Cabin for her suggestions on English language and sentence structure of manuscript. Authors ackowledge Prof. Subrata Sinha for his valuable suggestions on the presentation of the manuscript.

\section{Funding}

This work was supported by Ramalingaswami fellowship (BT/HRD/35/23/ 2006), Department of Biotechnology (DBT), New Delhi, a DBT grant (BT/ PR10721/Med/30/105/2008) and institutional core start-up fund to RKG. PSG and HS are supported by CSIR and UGC Fellowship, New Delhi, India respectively. The funders had no role in study design, data collection and analysis, decision to publish, or preparation of the manuscript.

\section{Author details}

${ }^{1}$ National Brain Research Centre, Manesar, Haryana, India. ${ }^{2}$ McLaughlin Research Institute, Great Falls, MT, USA. ${ }^{3}$ Molecular and Cellular Neuroscience Division, National Brain Research Centre, Manesar, Haryana 122051, India.

Received: 15 December 2013 Accepted: 7 March 2014 Published: 26 March 2014

\section{References}

Andersen K, Launer LJ, Dewey ME, Letenneur L, Ott A, Copeland JR, Dartigues JF, Kragh-Sorensen P, Baldereschi M, Brayne C, Lobo A, Martinez-Lage JM, Stijnen T, Hofman A (1999) Gender differences in the incidence of AD and vascular dementia: The EURODEM Studies. EURODEM Incidence Research Group. Neurology 53(9):1992-1997

Baldassarro VA, Lizzo G, Paradisi M, Fernandez M, Giardino L, Calza L (2013) Neural stem cells isolated from amyloid precursor protein-mutated mice for drug discovery. World J Stem Cells 5(4):229-237

Bibl M, Mollenhauer B, Esselmann H, Lewczuk P, Klafki HW, Sparbier K, Smirnov A, Cepek L, Trenkwalder C, Ruther E, Kornhuber J, Otto M, Wiltfang J (2006) CSF amyloid-beta-peptides in Alzheimer's disease, dementia with Lewy bodies and Parkinson's disease dementia. Brain 129(Pt 5):1177-1187

Borchelt DR, Davis J, Fischer M, Lee MK, Slunt HH, Ratovitsky T, Regard J, Copeland NG, Jenkins NA, Sisodia SS, Price DL (1996a) A vector for expressing foreign genes in the brains and hearts of transgenic mice. Genet Anal 13(6):159-163

Borchelt DR, Thinakaran G, Eckman CB, Lee MK, Davenport F, Ratovitsky T, Prada CM, Kim G, Seekins S, Yager D, Slunt HH, Wang R, Seeger M, Levey Al, Gandy SE, Copeland NG, Jenkins NA, Price DL, Younkin SG, Sisodia SS (1996b) Familial Alzheimer's disease-linked presenilin 1 variants elevate Abeta1-42/140 ratio in vitro and in vivo. Neuron 17(5):1005-1013

Brewer GJ, Torricelli JR (2007) Isolation and culture of adult neurons and neurospheres. Nat Protoc 2(6):1490-1498

Brustle O, Spiro AC, Karram K, Choudhary K, Okabe S, McKay RD (1997) In vitro-generated neural precursors participate in mammalian brain development. Proc Natl Acad Sci U S A 94(26):14809-14814

Cai XD, Golde TE, Younkin SG (1993) Release of excess amyloid beta protein from a mutant amyloid beta protein precursor. Science 259(5094):514-516

Chartier-Harlin MC, Crawford F, Houlden H, Warren A, Hughes D, Fidani L, Goate A, Rossor M, Roques P, Hardy J, Mullan M (1991) Early-onset Alzheimer's disease caused by mutations at codon 717 of the beta-amyloid precursor protein gene. Nature 353(6347):844-846

Cheng IH, Scearce-Levie K, Legleiter J, Palop JJ, Gerstein H, Bien-Ly N, Puolivali J, Lesne S, Ashe KH, Muchowski PJ, Mucke L (2007) Accelerating amyloid-beta fibrillization reduces oligomer levels and functional deficits in Alzheimer disease mouse models. J Biol Chem 282(33):23818-23828 
Christensen DZ, Bayer TA, Wirths O (2009) Formic acid is essential for immunohistochemical detection of aggregated intraneuronal Abeta peptides in mouse models of Alzheimer's disease. Brain Res 1301:116-125

Citron M, Westaway D, Xia W, Carlson G, Diehl T, Levesque G, Johnson-Wood K, Lee M, Seubert P, Davis A, Kholodenko D, Motter R, Sherrington R, Perry B, Yao H, Strome R, Lieberburg I, Rommens J, Kim S, Schenk D, Fraser P, St George Hyslop P, Selkoe DJ (1997) Mutant presenilins of Alzheimer's disease increase production of 42-residue amyloid beta-protein in both transfected cells and transgenic mice. Nat Med 3(1):67-72

Cleary JP, Walsh DM, Hofmeister JJ, Shankar GM, Kuskowski MA, Selkoe DJ, Ashe KH (2005) Natural oligomers of the amyloid-beta protein specifically disrupt cognitive function. Nat Neurosci 8(1):79-84

De Simoni A, Yu LM (2006) Preparation of organotypic hippocampal slice cultures: interface method. Nat Protoc 1(3):1439-1445

Deshpande A, Mina E, Glabe C, Busciglio J (2006) Different conformations of amyloid beta induce neurotoxicity by distinct mechanisms in human cortical neurons. J Neurosci 26(22):6011-6018

Draberova E, Del Valle L, Gordon J, Markova V, Smejkalova B, Bertrand L, de Chadarevian JP, Agamanolis DP, Legido A, Khalili K, Draber P, Katsetos CD (2008) Class III beta-tubulin is constitutively coexpressed with glial fibrillary acidic protein and nestin in midgestational human fetal astrocytes: implications for phenotypic identity. J Neuropathol Exp Neurol 67(4):341-354

Eimer WA, Vassar R (2013) Neuron loss in the 5XFAD mouse model of Alzheimer's disease correlates with intraneuronal Abeta42 accumulation and Caspase-3 activation. Mol Neurodegener 8:2

Fisher S, Gearhart JD, Oster-Granite ML (1991) Expression of the amyloid precursor protein gene in mouse oocytes and embryos. Proc Natl Acad Sci U S A 88(5):1779-1782

Giri RK, Selvaraj SK, Kalra VK (2003) Amyloid peptide-induced cytokine and chemokine expression in THP-1 monocytes is blocked by small inhibitory RNA duplexes for early growth response-1 messenger RNA. J Immunol 170(10):5281-5294

Giri RK, Young R, Pitstick R, DeArmond SJ, Prusiner SB, Carlson GA (2006) Prion infection of mouse neurospheres. Proc Natl Acad Sci U S A 103(10):3875-3880

Glenner GG, Wong CW (1984) Alzheimer's disease: initial report of the purification and characterization of a novel cerebrovascular amyloid protein. Biochem Biophys Res Commun 120(3):885-890

Goate A, Chartier-Harlin MC, Mullan M, Brown J, Crawford F, Fidani L, Giuffra L, Haynes A, Irving N, James L, Mant R, Newton P, Rooke K, Roques P, Talbot C, Pericak-Vance M, Roses A, Williamson R, Rossor M, Owen M, Hardy J (1991) Segregation of a missense mutation in the amyloid precursor protein gene with familial Alzheimer's disease. Nature 349(6311):704-706

Gritti A, Parati EA, Cova L, Frolichsthal P, Galli R, Wanke E, Faravelli L, Morassutti DJ, Roisen F, Nickel DD, Vescovi AL (1996) Multipotential stem cells from the adult mouse brain proliferate and self-renew in response to basic fibroblast growth factor. J Neurosci 16(3):1091-1100

Gubert F, Zaverucha-do-Valle C, Pimentel-Coelho PM, Mendez-Otero R, Santiago MF (2009) Radial glia-like cells persist in the adult rat brain. Brain Res 1258:43-52

Haass C, Schlossmacher MG, Hung AY, Vigo-Pelfrey C, Mellon A, Ostaszewski BL, Lieberburg I, Koo EH, Schenk D, Teplow DB, Selkoe DJ (1992) Amyloid beta-peptide is produced by cultured cells during normal metabolism. Nature 359(6393):322-325

Hardy J, Allsop D (1991) Amyloid deposition as the central event in the aetiology of Alzheimer's disease. Trends Pharmacol Sci 12(10):383-388

Haughey NJ, Nath A, Chan SL, Borchard AC, Rao MS, Mattson MP (2002) Disruption of neurogenesis by amyloid beta-peptide, and perturbed neural progenitor cell homeostasis, in models of Alzheimer's disease. J Neurochem 83(6):1509-1524

Herva ME, Relano-Gines A, Villa A, Torres JM (2010) Prion infection of differentiated neurospheres. J Neurosci Methods 188(2):270-275

Ida N, Hartmann T, Pantel J, Schroder J, Zerfass R, Forstl H, Sandbrink R, Masters CL, Beyreuther K (1996) Analysis of heterogeneous A4 peptides in human cerebrospinal fluid and blood by a newly developed sensitive Western blot assay. J Biol Chem 271(37):22908-22914

Ingelsson M, Fukumoto H, Newell KL, Growdon JH, Hedley-Whyte ET, Frosch MP, Albert MS, Hyman BT, Irizarry MC (2004) Early Abeta accumulation and progressive synaptic loss, gliosis, and tangle formation in AD brain. Neurology 62(6):925-931

Israel MA, Yuan SH, Bardy C, Reyna SM, Mu Y, Herrera C, Hefferan MP, Van Gorp S, Nazor KL, Boscolo FS, Carson CT, Laurent LC, Marsala M, Gage FH, Remes AM,
Koo EH, Goldstein LS (2012) Probing sporadic and familial Alzheimer's disease using induced pluripotent stem cells. Nature 482(7384):216-220

Jankowsky JL, Fadale DJ, Anderson J, Xu GM, Gonzales V, Jenkins NA, Copeland NG, Lee MK, Younkin LH, Wagner SL, Younkin SG, Borchelt DR (2004) Mutant presenilins specifically elevate the levels of the 42 residue beta-amyloid peptide in vivo: evidence for augmentation of a 42 -specific gamma secretase. Hum Mol Genet 13(2):159-170

Jin K, Peel AL, Mao XO, Xie L, Cottrell BA, Henshall DC, Greenberg DA (2004) Increased hippocampal neurogenesis in Alzheimer's disease. Proc Natl Acad Sci U S A 101(1):343-347

Kosik KS, Joachim CL, Selkoe DJ (1986) Microtubule-associated protein tau (tau) is a major antigenic component of paired helical filaments in Alzheimer disease. Proc Natl Acad Sci U S A 83(11):4044-4048

LeBlanc A (1995) Increased production of $4 \mathrm{kDa}$ amyloid beta peptide in serum deprived human primary neuron cultures: possible involvement of apoptosis. J Neurosci 15(12):7837-7846

LeBlanc AC, Papadopoulos M, Belair C, Chu W, Crosato M, Powell J, Goodyer CG (1997) Processing of amyloid precursor protein in human primary neuron and astrocyte cultures. J Neurochem 68(3):1183-1190

Lendahl U, Zimmerman LB, McKay RD (1990) CNS stem cells express a new class of intermediate filament protein. Cell 60(4):585-595

Lesne S, Koh MT, Kotilinek L, Kayed R, Glabe CG, Yang A, Gallagher M, Ashe KH (2006) A specific amyloid-beta protein assembly in the brain impairs memory. Nature 440(7082):352-357

Lesne SE, Sherman MA, Grant M, Kuskowski M, Schneider JA, Bennett DA, Ashe KH (2013) Brain amyloid-beta oligomers in ageing and Alzheimer's disease. Brain 136(Pt 5):1383-1398

Levy-Lahad E, Wasco W, Poorkaj P, Romano DM, Oshima J, Pettingell WH, Yu CE, Jondro PD, Schmidt SD, Wang K, Crowley AC, Fu Y-H, Guenette SY, Galas D, Nemens E, Wijsman EM, Bird TD, Schellenberg GD, Tanzi RE (1995) Candidate gene for the chromosome 1 familial Alzheimer's disease locus. Science 269(5226):973-977

Lopez-Toledano MA, Shelanski ML (2004) Neurogenic effect of beta-amyloid peptide in the development of neural stem cells. J Neurosci 24(23):5439-5444

Lorenzo A, Yankner BA (1994) Beta-amyloid neurotoxicity requires fibril formation and is inhibited by congo red. Proc Natl Acad Sci U S A 91(25):12243-12247

Lue LF, Kuo YM, Roher AE, Brachova L, Shen Y, Sue L, Beach T, Kurth JH, Rydel RE, Rogers J (1999) Soluble amyloid beta peptide concentration as a predictor of synaptic change in Alzheimer's disease. Am J Pathol 155(3):853-862

Oakley H, Cole SL, Logan S, Maus E, Shao P, Craft J, Guillozet-Bongaarts A, Ohno M, Disterhoft J, Van Eldik L, Berry R, Vassar R (2006) Intraneuronal beta-amyloid aggregates, neurodegeneration, and neuron loss in transgenic mice with five familial Alzheimer's disease mutations: potential factors in amyloid plaque formation. J Neurosci 26(40):10129-10140

Oddo S, Caccamo A, Smith IF, Green KN, LaFerla FM (2006) A dynamic relationship between intracellular and extracellular pools of Abeta. Am J Pathol 168(1):184-194

Orr ME, Pitstick R, Canine B, Ashe KH, Carlson GA (2012) Genotype-specific differences between mouse CNS stem cell lines expressing frontotemporal dementia mutant or wild type human tau. PLoS One 7(6):e39328

Ray J, Gage FH (2006) Differential properties of adult rat and mouse brain-derived neural stem/progenitor cells. Mol Cell Neurosci 31(3):560-573

Reynolds BA, Weiss S (1992) Generation of neurons and astrocytes from isolated cells of the adult mammalian central nervous system. Science 255 (5052):1707-1710

Rodriguez JJ, Olabarria M, Chvatal A, Verkhratsky A (2009) Astroglia in dementia and Alzheimer's disease. Cell Death Differ 16(3):378-385

Rosen RF, Tomidokoro Y, Ghiso JA, Walker LC (2010) SDS-PAGE/immunoblot detection of Abeta multimers in human cortical tissue homogenates using antigen-epitope retrieval. J Vis Exp 38:1-4

Scheuner D, Eckman C, Jensen M, Song X, Citron M, Suzuki N, Bird TD, Hardy J, Hutton M, Kukull W, Larson E, Levy-Lahad E, Viitanen M, Peskind E, Poorkaj P, Schellenberg G, Tanzi R, Wasco W, Lannfelt L, Selkoe D, Younkin S (1996) Secreted amyloid beta-protein similar to that in the senile plaques of Alzheimer's disease is increased in vivo by the presenilin 1 and 2 and APP mutations linked to familial Alzheimer's disease. Nat Med 2(8):864-870

Selkoe DJ (2002) Alzheimer's disease is a synaptic failure. Science 298(5594):789-791 Sherrington R, Rogaev El, Liang Y, Rogaeva EA, Levesque G, Ikeda M, Chi H, Lin C, Li G, Holman K, Tsuda T, Mar L, Foncin JF, Bruni AC, Montesi MP, Sorbi S, Rainero I, Pinessi L, Nee L, Chumakov I, Pollen D, Brookes A, Sanseau P, Polinsky RJ, Wasco W, Da Silva HA, Haines JL, Perkicak-Vance MA, Tanzi RE, 
Roses AD et al (1995) Cloning of a gene bearing missense mutations in early-onset familial Alzheimer's disease. Nature 375(6534):754-760

Sierksma AS, Prickaerts J, Chouliaras L, Rostamian S, Delbroek L, Rutten BP, Steinbusch HW, van den Hove DL (2013) Behavioral and neurobiological effects of prenatal stress exposure in male and female APPswe/PS1dE9 mice. Neurobiol Aging 34(1):319-337

Skaper SD, Evans NA, Evans NA, Rosin C, Facci L, Richardson JC (2009) Oligodendrocytes are a novel source of amyloid peptide generation. Neurochem Res 34(12):2243-2250

Sommer B (2002) Alzheimer's disease and the amyloid cascade hypothesis: ten years on. Curr Opin Pharmacol 2(1):87-92

St George-Hyslop PH, Tanzi RE, Polinsky RJ, Haines JL, Nee L, Watkins PC, Myers RH, Feldman RG, Pollen D, Drachman D, Growdon J, Bruni A, Foncin J-F, Salmon D, Frommelt P, Amaducci L, Sorbi S, Piacentini S, Stewart GD, Hobbs WJ, Conneally PM, Gusella JF (1987) The genetic defect causing familial Alzheimer's disease maps on chromosome 21. Science 235(4791):885-890

Swerdlow PS, Finley D, Varshavsky A (1986) Enhancement of immunoblot sensitivity by heating of hydrated filters. Anal Biochem 156(1):147-153

Takahashi RH, Milner TA, Li F, Nam EE, Edgar MA, Yamaguchi H, Beal MF, Xu H, Greengard P, Gouras GK (2002) Intraneuronal Alzheimer abeta42 accumulates in multivesicular bodies and is associated with synaptic pathology. Am J Pathol 161(5):1869-1879

Takashima A, Noguchi K, Sato K, Hoshino T, Imahori K (1993) Tau protein kinase I is essential for amyloid beta-protein-induced neurotoxicity. Proc Natl Acad Sci U S A 90(16):7789-7793

Tomita T, Maruyama K, Saido TC, Kume H, Shinozaki K, Tokuhiro S, Capell A, Walter J, Grunberg J, Haass C, Iwatsubo T, Obata K (1997) The presenilin 2 mutation (N141I) linked to familial Alzheimer disease (Volga German families) increases the secretion of amyloid beta protein ending at the 42nd (or 43rd) residue. Proc Natl Acad Sci U S A 94(5):2025-2030

Trinchese F, Liu S, Ninan I, Puzzo D, Jacob JP, Arancio O (2004) Cell cultures from animal models of Alzheimer's disease as a tool for faster screening and testing of drug efficacy. J Mol Neurosci 24(1):15-21

Uchida N, Buck DW, He D, Reitsma MJ, Masek M, Phan TV, Tsukamoto AS, Gage FH, Weissman IL (2000) Direct isolation of human central nervous system stem cells. Proc Natl Acad Sci U S A 97(26):14720-14725

Usenko T, Li YJ, Haeri M, Li Y, Vecchiarelli-Federico LM, Zhao X, Prchal JT, Ben-David Y (2009) Enrichment of Sca1+ hematopoietic progenitors in polycythemic mice inhibits leukemogenesis. Blood 114(9):1831-1841

Vassar R, Bennett BD, Babu-Khan S, Kahn S, Mendiaz EA, Denis P, Teplow DB, Ross S, Amarante P, Loeloff R, Luo Y, Fisher S, Fuller J, Edenson S, Lile J, Jarosinski MA, Biere AL, Curran E, Burgess T, Louis JC, Collins F, Treanor J, Rogers G, Citron M (1999) Beta-secretase cleavage of Alzheimer's amyloid precursor protein by the transmembrane aspartic protease BACE. Science 286(5440):735-74

Walsh DM, Tseng BP, Rydel RE, Podlisny MB, Selkoe DJ (2000) The oligomerization of amyloid beta-protein begins intracellularly in cells derived from human brain. Biochemistry 39(35):10831-10839

Walsh DM, Klyubin I, Fadeeva JV, Cullen WK, Anwyl R, Wolfe MS, Rowan MJ, Selkoe DJ (2002) Naturally secreted oligomers of amyloid beta protein potently inhibit hippocampal long-term potentiation in vivo. Nature 416(6880):535-539

Wang J, Dickson DW, Trojanowski JQ, Lee VM (1999) The levels of soluble versus insoluble brain Abeta distinguish Alzheimer's disease from normal and pathologic aging. Exp Neurol 158(2):328-337

Wang HY, Lee DH, D'Andrea MR, Peterson PA, Shank RP, Reitz AB (2000) beta-Amyloid(1-42) binds to alpha7 nicotinic acetylcholine receptor with high affinity. Implications for Alzheimer's disease pathology. J Biol Chem 275(8):5626-5632

Wang J, Tanila H, Puolivali J, Kadish I, van Groen T (2003) Gender differences in the amount and deposition of amyloidbeta in APPswe and PS1 double transgenic mice. Neurobiol Dis 14(3):318-327

Wei LC, Shi M, Chen LW, Cao R, Zhang P, Chan YS (2002) Nestin-containing cells express glial fibrillary acidic protein in the proliferative regions of central nervous system of postnatal developing and adult mice. Brain Res Dev Brain Res 139(1):9-17

Wertkin AM, Turner RS, Pleasure SJ, Golde TE, Younkin SG, Trojanowski JQ, Lee VM (1993) Human neurons derived from a teratocarcinoma cell line express solely the 695-amino acid amyloid precursor protein and produce intracellular beta-amyloid or A4 peptides. Proc Natl Acad Sci U S A 90(20):9513-9517
Whitehouse PJ, Price DL, Struble RG, Clark AW, Coyle JT, Delon MR (1982) Alzheimer's disease and senile dementia: loss of neurons in the basal forebrain. Science 215(4537):1237-1239

Wiltfang J, Smirnov A, Schnierstein B, Kelemen G, Matthies U, Klafki HW Staufenbiel M, Huther G, Ruther E, Kornhuber J (1997) Improved electrophoretic separation and immunoblotting of beta-amyloid (A beta) peptides 1-40, 1-42, and 1-43. Electrophoresis 18(3-4):527-532

Wirths O, Multhaup G, Czech C, Blanchard V, Moussaoui S, Tremp G, Pradier L, Beyreuther K, Bayer TA (2001) Intraneuronal Abeta accumulation precedes plaque formation in beta-amyloid precursor protein and presenilin-1 double-transgenic mice. Neurosci Lett 306(1-2):116-120

Wood JG, Mirra SS, Pollock NJ, Binder LI (1986) Neurofibrillary tangles of Alzheimer disease share antigenic determinants with the axonal microtubule-associated protein tau (tau). Proc Natl Acad Sci U S A 83 (11):4040-4043

Yagi T, Ito D, Okada Y, Akamatsu W, Nihei Y, Yoshizaki T, Yamanaka S, Okano H, Suzuki N (2011) Modeling familial Alzheimer's disease with induced pluripotent stem cells. Hum Mol Genet 20(23):4530-4539

Yankner BA, Duffy LK, Kirschner DA (1990) Neurotrophic and neurotoxic effects of amyloid beta protein: reversal by tachykinin neuropeptides. Science 250(4978):279-282

Youmans KL, Tai LM, Kanekiyo T, Stine WB Jr, Michon SC, Nwabuisi-Heath E, Manelli AM, Fu Y, Riordan S, Eimer WA, Binder L, Bu G, Yu C, Hartley DM, LaDu MJ (2012) Intraneuronal Abeta detection in 5xFAD mice by a new Abeta-specific antibody. Mol Neurodegener 7:8

Yun SW, Kouznetsova E, Nitschke C, Heinitz K, Schliebs R, Gerlach M, Riederer P, Klein MA (2007) beta-Amyloid deposition and prion infection in adult primary brain cell long-term culture model. Biochem Biophys Res Commun 360(3):520-524

Zecevic N (2004) Specific characteristic of radial glia in the human fetal telencephalon. Glia 48(1):27-35

doi:10.1186/2193-1801-3-161

Cite this article as: Ghate et al:: Development of a novel cellular model of Alzheimer's disease utilizing neurosphere cultures derived from B6C3-Tg(APPswe,PSEN1dE9)85Dbo/J embryonic mouse brain. SpringerPlus 2014 3:161

\section{Submit your manuscript to a SpringerOpen ${ }^{\circ}$ journal and benefit from:}

- Convenient online submission

- Rigorous peer review

- Immediate publication on acceptance

- Open access: articles freely available online

- High visibility within the field

- Retaining the copyright to your article

Submit your next manuscript at $\gg$ springeropen.com 